\title{
The Effects of Cannabidiol and Prognostic Role of TRPV2 in Human Endometrial Cancer
}

\author{
Oliviero Marinelli ${ }^{1,+} \mathbb{C}^{\circ}$, Maria Beatrice Morelli ${ }^{1,+}+\mathbb{C}$, Daniela Annibali ${ }^{2}\left(\mathbb{D}\right.$, Cristina Aguzzi $^{1}$, \\ Laura Zeppa ${ }^{1}$, Sandra Tuyaerts ${ }^{2} \mathbb{D}$, Consuelo Amantini ${ }^{3}$, Frédéric Amant ${ }^{2,4}$, Benedetta Ferretti ${ }^{5}$, \\ Federica Maggi ${ }^{6}$ (D), Giorgio Santoni ${ }^{1}$ and Massimo Nabissi ${ }^{1,7, *(1)}$ \\ 1 School of Pharmacy, University of Camerino, 62032 Camerino (MC), Italy; \\ oliviero.marinelli@unicam.it (O.M.); mariabeatrice.morelli@unicam.it (M.B.M.); \\ aguzzicristina02@gmail.com (C.A.); laura.zeppa.95@gmail.com (L.Z.); giorgio.santoni@unicam.it (G.S.) \\ 2 Gynecological Oncology Department LKI, Leuven Cancer Institute KU, Leuven-University of Leuven, \\ 3000 Leuven, Belgium; daniela.annibali@kuleuven.be (D.A.); sandra.tuyaerts@kuleuven.be (S.T.); \\ frederic.amant@kuleuven.be (F.A.) \\ 3 School of Bioscience and Veterinary Medicine, University of Camerino, 62032 Camerino (MC), Italy; \\ consuelo.amantini@unicam.it \\ 4 Centre for Gynecologic Oncology Amsterdam (CGOA), Antoni Van Leeuwenhoek-Netherlands Cancer \\ Institute (AvL-NKI), University Medical Centra (UMC), 1066 Amsterdam, The Netherlands \\ 5 Oncologia Medica, Ospedale di San Severino, 62027 San Severino Marche (MC), Italy; \\ benedetta.ferretti@sanita.marche.it \\ 6 Department of Molecular Medicine, Sapienza University, 00155 Rome, Italy; federica.maggi@uniroma1.it \\ 7 Integrative Therapy Discovery Lab, University of Camerino, 62032 Camerino (MC), Italy \\ * Correspondence: massimo.nabissi@unicam.it; Tel.: +39-0737-403306 \\ + These authors contributed equally to this work.
}

Received: 29 June 2020; Accepted: 29 July 2020; Published: 29 July 2020

check for updates

\begin{abstract}
Several studies support, both in vitro and in vivo, the anti-cancer effects of cannabidiol (CBD), a transient receptor potential vanilloid 2 (TRPV2) ligand. TRPV2, often dysregulated in tumors, is associated with altered cell proliferation and aggressiveness. Endometrial cancer (EC) is historically divided in type I endometrioid EC and type II non-endometrioid EC, associated with poor prognosis. Treatment options with chemotherapy and combinations with radiation showed only limited efficacy. Since no data are reported concerning TRPV2 expression as well as CBD potential effects in EC, the aim of this study was to evaluate the expression of TRPV2 in biopsies and cell lines as well as the effects of CBD in in vitro models. Overall survival (OS), progression-free survival (PFS), cell viability, migration, and chemo-resistance have been evaluated. Results show that TRPV2 expression increased with the malignancy of the cancer tissue and correlated with shorter PFS $(p=0.0224)$. Moreover, in vitro TRPV2 over-expression in Ishikawa cell line increased migratory ability and response to cisplatin. CBD reduced cell viability, activating predominantly apoptosis in type I cells and autophagy in mixed type EC cells. The CBD improved chemotherapeutic drugs cytotoxic effects, enhanced by TRPV2 over-expression. Hence, TRPV2 could be considered as a marker for optimizing the therapy and CBD might be a useful therapeutic option as adjuvant therapy.
\end{abstract}

Keywords: cannabidiol; TRPV2; endometrial cancer; progression-free survival; migration; chemo-resistance

\section{Introduction}

Medical Cannabis (MC) and pure phyto-cannabinoids (as tetrahydrocannabinol, THC and cannabidiol, CBD) have been largely studied for their ability to ameliorate some of the most common and debilitating symptoms in cancer patients, like nausea, vomiting and pain [1,2]. 
In addition to these effects, $\mathrm{MC}$ and THC/CBD have attracted attention as potential anti-tumoral drugs, mainly as adjuvant for current therapies in different type of cancers [3]. The main non-psychotropic cannabinoid compound, CBD, is present in the $\mathrm{MC}$ and is a potent inhibitor of different cancer properties, such as proliferation, migration and chemo-resistance in pre-clinical studies [3]. Anti-cancer effect of CBD is demonstrated in glioblastoma (GBM) [4-6], lung [7-9], gastric [10], breast [11-13], melanoma [14], prostate [15] and colon [16,17] cancers, neuroblastoma [18], multiple myeloma (MM) [19,20], leukaemia [21,22], pancreatic and endometrial cancers [23,24]. In addition, $\mathrm{CBD}$ has been shown to synergize with bortezomib and temozolomide in reducing cell growth and survival pathways in MM [19] and glioma cell lines [25], respectively.

It can exert its biological activities via dependent (D)- and independent (ID)-receptors mechanisms (RMs). D-RMs mainly include weak antagonistic effects on cannabinoid receptor type-1 and -2 (CB1, CB2) [26], agonist effects on some cation channels of the transient receptor potential (TRP) superfamily as vanilloid type 1-4 (TRPV1, TRPV2, TRPV3 and TRPV4), ankyrin 1 (TRPA1) and antagonist effects on TRP mammalian type 8 (TRPM8) $[27,28]$. Cannabidiol-related ID-RMs effects have also been described in cancer and are mainly based on evidences obtained in cell lines where the CBD receptors (CB1/CB2/TRPs) are not detected [20,29].

Regarding TRPV2, its expression and activation by CBD have been associated with deregulation of proliferation, cell differentiation and invasiveness in different cancer cell lines and animal models [30]. Briefly, TRPV2 over-expression was described in high-grade urothelial cancers' biopsies and CBD-treatment induces apoptosis in bladder cancer cells [31,32]. In bladder and prostate cancers, TRPV2 stimulates migration and invasion [33-35]. Recently, it has been reported that TRPV2 should be considered a prognostic marker for triple negative and ER $\beta$ - breast cancer patients [13]. In addition, CBD induces a TRPV2-dependent differentiation and thus it sensitizes human glioma stem-like cells to chemotherapeutic drugs [4]. In MM, over-expressing TRPV2 cells are more susceptible to the effects of CBD [19].

Endometrial cancer (EC) is the most commonly diagnosed gynecological malignancy in developed countries. ECs are divided into two subtypes, type I endometrioid EC and type II non-endometrioid EC. Type I is well differentiated and is frequently associated with a hyper estrogenic environment. Type II carcinomas develop from atrophic endometrium and are classified in different histological subgroups (e.g., serous and clear cell adenocarcinomas). These subtypes are poorly differentiated and associated with dismal prognosis [36,37]. Treatment options are hysterectomy, chemotherapy, such as triplet therapy with paclitaxel (PAC), cisplatin (CIS), and doxorubicin (DOX), and combinations with radiation, but only limited options remain if the tumors relapse or metastasize [38]. Expression of CB1 and CB2 was evidenced to decrease in endometrial biopsies from women with EC compared to benign conditions, such as uterine prolapse, suggesting that $\mathrm{CB}$ receptors are potentially involved in progression of EC [39]. Thus, they should be useful as histological markers and therapeutic targets in the treatment or prevention of EC. In addition, expression of TRPV1 channels was demonstrated in EC cell lines and CBD was observed to induce cell death through TRPV1 only in a type I EC cell line [24]. Additional data on TRP channels have been reported in endometrial biopsies, where the levels of TRPV2, TRPV4, TRPM4, TRPM7, TRPC1, TRPC3, TRPC4, and TRPC6 channels were shown to fluctuate throughout the menstrual cycle in human endometrial stromal cells [40]. TRPV2, TRPV4, TRPC1/4, and TRPC6 were also present on biopsies derived from endometriosis patients; however, no correlation was found with endometriosis [41].

Since no data have been reported about TRPV2 expression in EC and there is a relative lack of robust diagnostic/prognostic biomarkers especially for EC type II, we firstly analyzed TRPV2 in human type II EC biopsies, and then, by in vitro investigations, we analyzed the TRPV2-dependent effects on cell migration and chemo-sensitivity. In addition, we evaluated the anticancer effects of CBD on EC cell lines. 


\section{Results}

\subsection{CB Receptors and TRPVs Gene Expression in EC Samples from TCGA}

We assessed $C B$ receptors and TRPV1/2 gene expression in 506 EC data samples from TCGA, queried with cBioportal (TCGA, PanCancer Atlas). Samples were divided in type I endometrioid (397 samples) and type II serous type (109 samples).

In serous type samples, $C B 1$ receptor was highly expressed $(p<0.001), C B 2$ was not expressed in both types. TRPV1 and TRPV2 were expressed in EC samples of both types. TRPV1 was more expressed in serous subtype $(p<0.05)$ while TRPV2 was more expressed in endometrioid subtype $(p<0.05)$ (Figure 1).
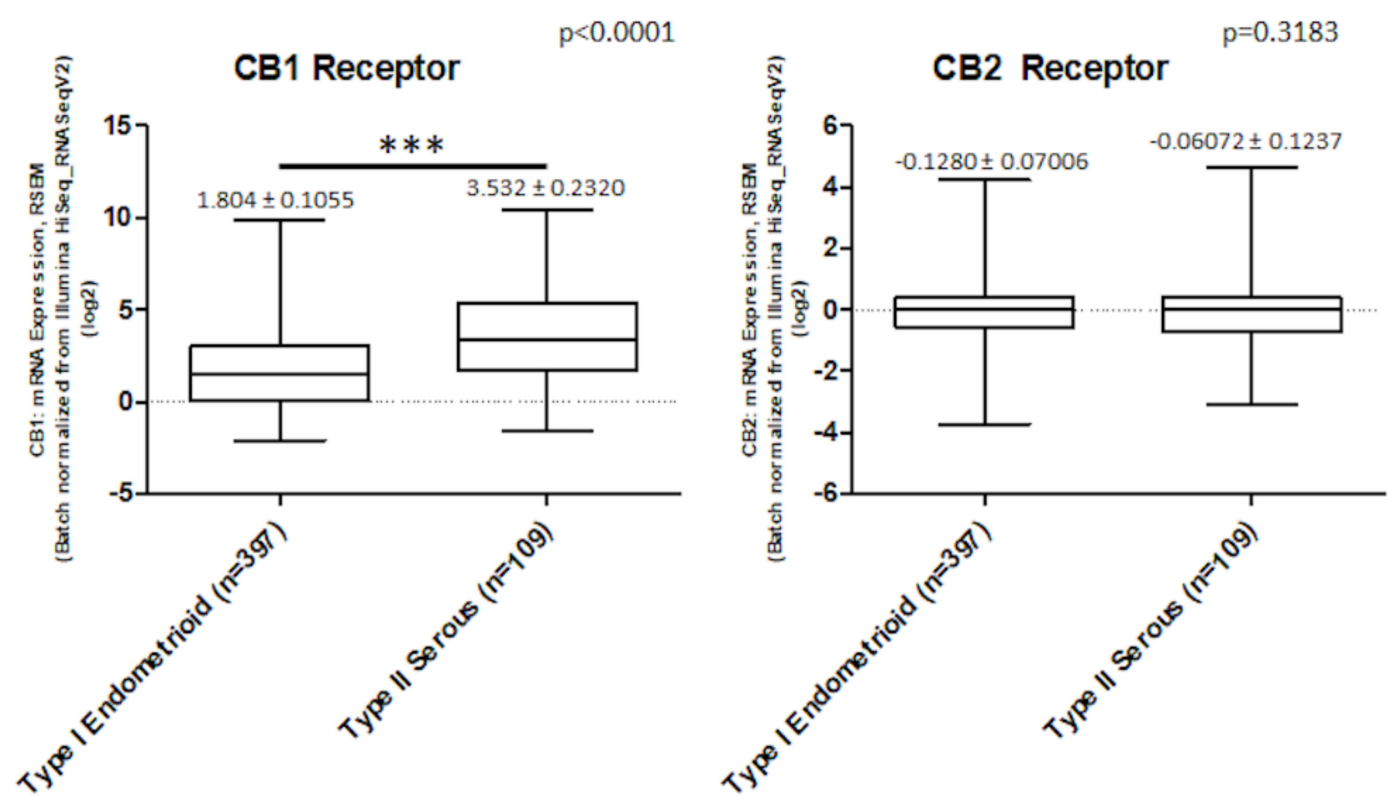

$\mathrm{p}=0.0313$
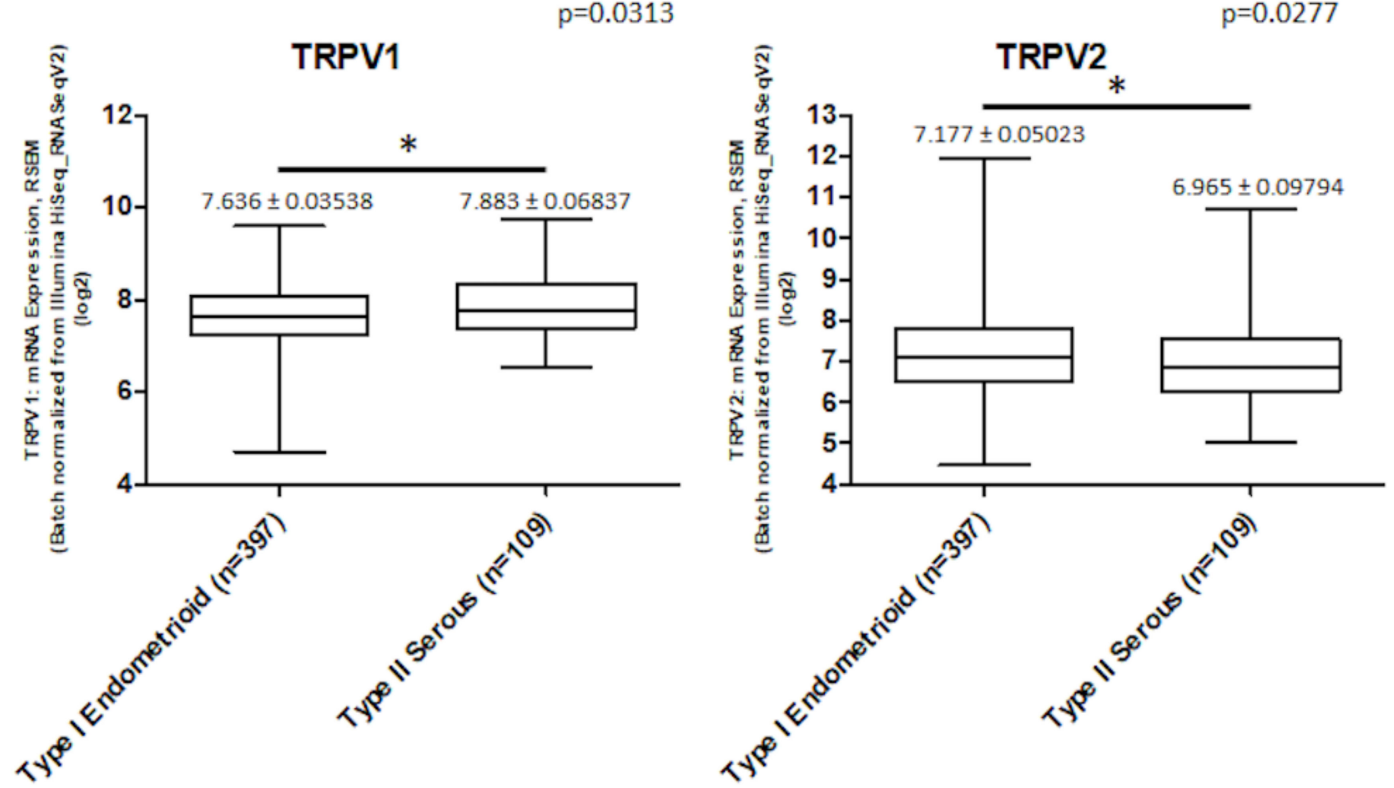

Figure 1. The expression of CBD (cannabidiol) targets in EC (endometrial cancer) patients. The mRNA expression (log RNA Seq V2 RSEM) of CB1, CB2, TRPV1 and TRPV2 in 506 EC samples, divided in 397 for type I and 109 for type II, from TCGA database. ${ }^{* * *} p<0.001$ type II vs. type I, ${ }^{*} p<0.05$ type II vs. type I. 
According to evidences in patients and since no data were available about TRPV2 and EC, we focused the attention on this channel.

\subsection{TRPV2 Expression Increased with the Increasing of Non-Endometrioid Component}

In order to evaluate the biological role of TRPV2 in EC, we measured the expression of TRPV2 in Ishikawa, MFE-280, HEC-1a and PCEM002 cell lines as type I EC models and PCEM004a and PCEM004b cell lines as mixed type I/II EC models, by RT-PCR and Western blot analysis. Results showed that all EC cell lines express low levels of TRPV2 mRNA, although PCEM004a and b display a higher amount compared to the others (Figure 2A). We further analyzed if there was a difference between type I and mixed type cell lines by Western blot. Immunoblots demonstrated the TRPV2 protein expression only in mixed type I/II PCEM004 cells, and this expression increased with the increasing of non-endometrioid component (Figure 2B).

A

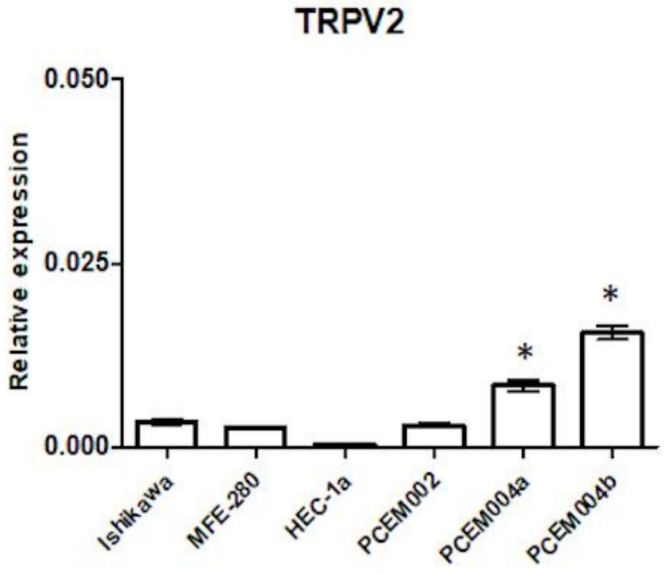

B

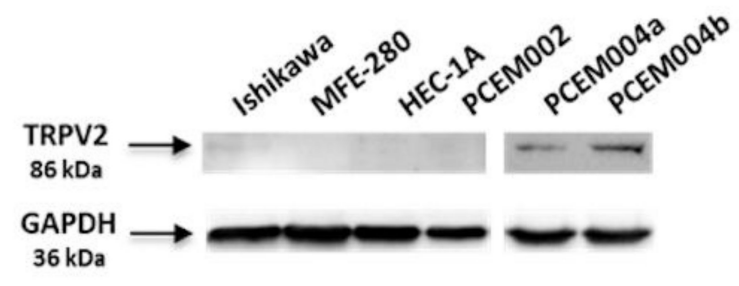

TRPV2

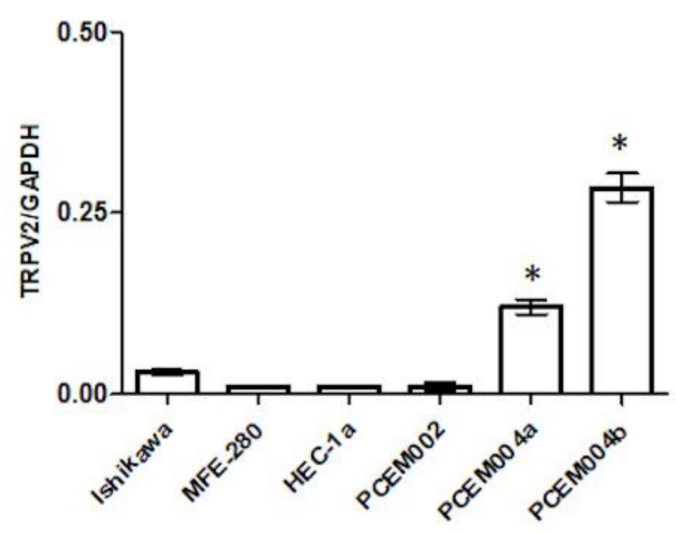

Figure 2. TRPV2 expression on EC cell lines. (A) TRPV2 mRNA expression was evaluated by quantitative real time-PCR (qRT-PCR) in six EC cell lines. TRPV2 mRNA levels were normalized for glyceraldehyde-3-phosphate dehydrogenase $(G A P D H)$ expression. Data are expressed as fold mean \pm standard deviation (SD) of three separate experiments. ${ }^{*} p<0.05$ vs. type I EC cell lines (B) TRPV2 protein expression was evaluated by Western blot in six EC cell lines. TRPV2 densitometry values were normalized to GAPDH used as loading control. Densitometric values shown are the mean \pm SD of three separate experiments. ${ }^{*} p<0.05$ vs. type I EC cell lines.

These results prompted us to investigate the correlation between TRPV2 expression levels and clinical parameters in a cohort of EC type II patients. 


\subsection{TRPV2 Expression Increased with the Malignancy of Type II EC and Correlated with a Shorter PFS}

TRPV2 expression level was determined in a total of 68 cases, including serous, clear cell, mixed type, peritumoral tissues and normal endometrium. Expression data are summarized in Table 1 and Supplementary Figure S1, divided for histological subgroups, International Federation of Gynecology and Obstetrics (FIGO) stage and age.

Table 1. Expression of TRPV2 in EC biopsies according to different clinicopathological characteristics, in EC biopsies, peritumoral tissue and normal endometrium. Percentages of samples positive for TRPV2 expression are shown.

\begin{tabular}{|c|c|c|c|}
\hline & \multicolumn{3}{|c|}{ TRPV2 } \\
\hline & High & Moderate & Low \\
\hline Tumor & $10 / 53(18.86 \%)$ & $16 / 53(30.19 \%)$ & $27 / 53(50.94 \%)$ \\
\hline Serous & $7 / 29(24.13 \%)$ & $9 / 29(31.03 \%)$ & $13 / 29(45.89 \%)$ \\
\hline Clear cell & $1 / 7(14.28 \%)$ & $1 / 7(14.28 \%)$ & $5 / 7(71.43 \%)$ \\
\hline Mixed & $2 / 17(11.76 \%)$ & $6 / 17(35.29 \%)$ & $9 / 17(52.94 \%)$ \\
\hline Peritumoral tissue & $0 / 5(0 \%)$ & $1 / 5(20 \%)$ & $4 / 5(80 \%)$ \\
\hline Normal endometrium & $0 / 10(0 \%)$ & $4 / 10(40 \%)$ & $6 / 10(60 \%)$ \\
\hline \multicolumn{4}{|l|}{ FIGO stage } \\
\hline Stage I-II & $3 / 20(15 \%)$ & $5 / 20(25 \%)$ & $12 / 20(60 \%)$ \\
\hline Serous & $1 / 10(10 \%)$ & $3 / 10(30 \%)$ & $6 / 10(60 \%)$ \\
\hline Clear cell & $0 / 2(0 \%)$ & $1 / 2(50 \%)$ & $1 / 2(50 \%)$ \\
\hline Mixed & $2 / 8(25 \%)$ & $1 / 8(12.5 \%)$ & $5 / 8(62.5 \%)$ \\
\hline Stage III & $3 / 17(17.65 \%)$ & $6 / 17(35.29 \%)$ & $8 / 17(47.06 \%)$ \\
\hline Serous & $3 / 10(30 \%)$ & $4 / 10(40 \%)$ & $3 / 10(30 \%)$ \\
\hline Clear cell & $0 / 2(0 \%)$ & $0 / 2(0 \%)$ & $2 / 2(100 \%)$ \\
\hline Mixed & $0 / 5(0 \%)$ & $2 / 5(40 \%)$ & $3 / 5(60 \%)$ \\
\hline Stage IV & $4 / 16(25 \%)$ & $5 / 16(31.25 \%)$ & $7 / 16(43.75 \%)$ \\
\hline Serous & $4 / 9(44.44 \%)$ & $2 / 9(22.22 \%)$ & $3 / 9(33.33 \%)$ \\
\hline Clear cell & $1 / 3(33.33 \%)$ & $0 / 3(0 \%)$ & $2 / 3(66.66 \%)$ \\
\hline Mixed & $0 / 4$ & $3 / 4(75 \%)$ & $1 / 4(25 \%)$ \\
\hline \multicolumn{4}{|l|}{ Age } \\
\hline$\leq 68$ & $4 / 26(15.38 \%)$ & $6 / 26(23.07 \%)$ & $16 / 26(61.54 \%)$ \\
\hline$>68$ & $6 / 27(22.22 \%)$ & $10 / 27(37.04 \%)$ & $11 / 27(40.74 \%)$ \\
\hline
\end{tabular}

Representative images for staining and score are shown in Figure S1A. Tissues were considered "high" at a score of 6 or higher, corresponding to weak staining in $\geq 67 \%$ of cells, moderate staining in $\geq 34 \%$ or strong staining in $>10 \%$ of cells. "Moderate" staining was at a score of $4-5$.

Highly expression of TRPV2 was found in $18.86 \%$ of tumor specimens, $30.19 \%$ were moderate and $50.94 \%$ stained low or negative. It was expressed in the epithelial component for $43.48 \%$ of specimens and in both stromal and epithelial components in 50\% of samples. The highest score was most frequently detected in serous type $(24.13 \%)$ while the lowest staining was found in clear cell type $(71.43 \%)$. Regarding peritumoral and normal tissues, TRPV2 was predominantly moderate or low. Samples were classified according to FIGO staging system and we found that TRPV2 expression increases with increasing of tissue malignancy. No significant difference in TRPV2 expression was detected in patients $\leq 68$ or $>68$ years, according to the median age. Furthermore, Kaplan-Meier analysis was performed, calculating overall survival (OS) and progression-free survival (PFS).

Kaplan-Meier analysis revealed that TRPV2 expression did not correlate with OS (TRPV2 ${ }^{\text {high }}$ 37 months vs. TRPV2 ${ }^{\text {moderate }} 53$ months, $p=0.9346, \mathrm{HR}=1.039,95 \% \mathrm{CI}=0.4131$ to 2.615, 
TRPV2 $2^{\text {high }} 37$ months vs. TRPV2 ${ }^{\text {low }} 43$ months, $p=1.326, \mathrm{HR}=1.039,95 \% \mathrm{CI}=0.5579$ to 3.149 , TRPV2 ${ }^{\text {moderate }} 53$ months vs. TRPV2 ${ }^{\text {low }} 43$ months, $p=1.326, \mathrm{HR}=1.199,95 \% \mathrm{CI}=0.5665$ to 2.537 ). High TRPV2 expression correlated with a shorter PFS (TRPV2 $2^{\text {high }}$ vs. TRPV2 ${ }^{\text {low }} p=0.0224, \mathrm{HR}=4.675$, $95 \% \mathrm{CI}=1.244$ to $17.57, \mathrm{TRPV} 2^{\text {high }}$ vs. TRPV2 ${ }^{\text {moderate }}, p=0.1172, \mathrm{HR}=2.755,95 \% \mathrm{CI}=0.7754$ to 9.790 , TRPV2 ${ }^{\text {moderate }}$ vs. TRPV2 ${ }^{\text {low }}, p=0.6896, \mathrm{HR}=1.232,95 \% \mathrm{CI}=0.4433$ to 3.422 ) (Figure 3).

\section{TRPV2 Overall Survival}

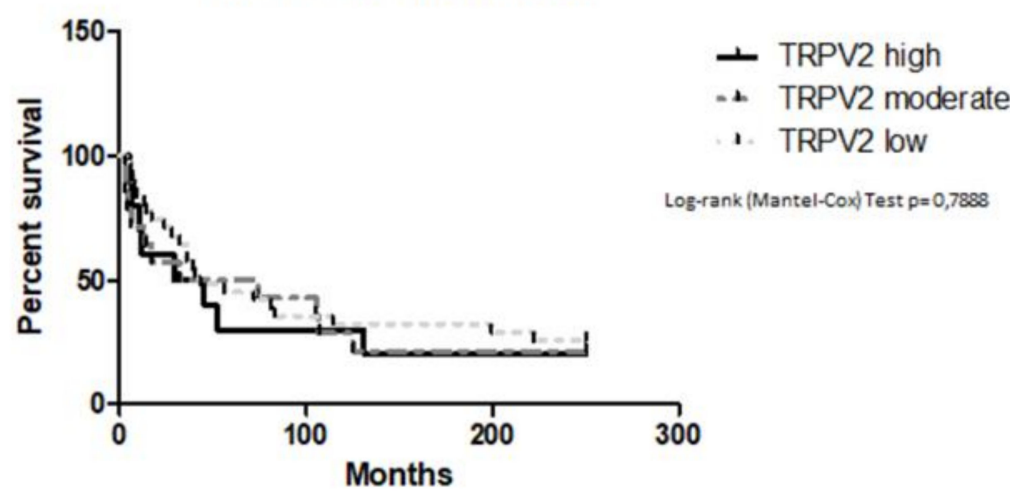

TRPV2 Progression-Free Survival

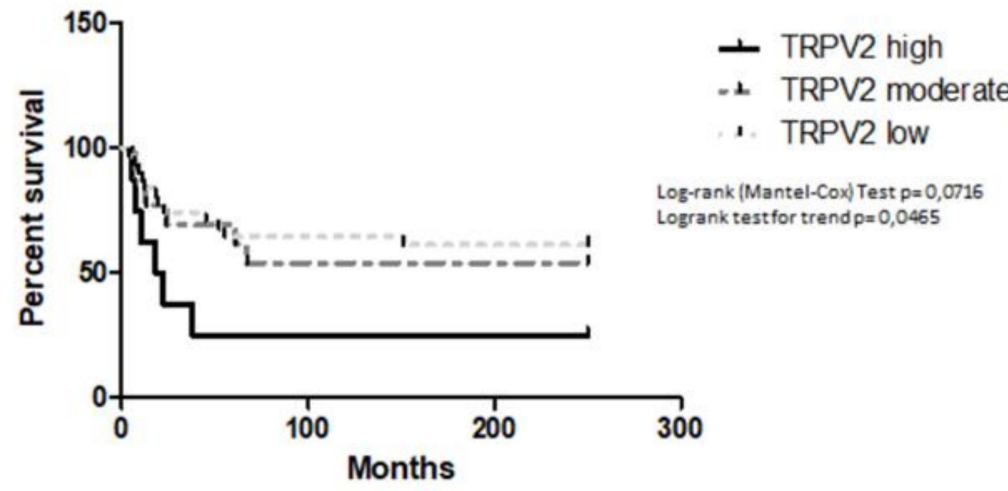

Figure 3. Survival of EC patients according to TRPV2 expression. Kaplan-Meier survival curves showing OS (overall survival) and PFS (progression-free survival) of EC patients. The log-rank test with corresponding P values applies to the TRPV2-high, TRPV2-moderate and TRPV2-low curves.

Additionally, OS and PFS were calculated according to TRPV2 distribution, dividing patients according to TRPV2 expression in tumor, stroma, or both (tumor + stroma). Stroma subgroup was excluded because there were too few patients for statistical analysis. Intra-tumoral TRPV2 distribution did not influence OS outcome $(p>0.05, \mathrm{HR}=0.6764,95 \% \mathrm{CI}=0.3391$ to 1.349$)$ or PFS ( $p>0.05$, $\mathrm{HR}=0.8102,95 \% \mathrm{CI}=0.3201$ to 2.051 ) (Figure 4 ).

Taken together, our data showed that TRPV2 expression correlates with malignancy in non-endometrioid EC and supported the investigation of CBD biological effects in EC.

\subsection{TRPV2 Expression Stimulated Migration and Survival of EC Cells}

According to data obtained in patients, we decided to investigate the role of TRPV2 on proliferation and migration of Ishikawa cells, which show low TRPV2 expression. Cells were firstly transfected with TRPV2 expressing vector (TRPV2 ${ }^{+}$cells) and TRPV2 expression was subsequently confirmed by Western blot analysis (Figure 5A). The result showed that TRPV2 ${ }^{+}$cells exhibited higher migratory capacities compared with untransfected cells, after $48 \mathrm{~h}$, as determined by the wound-healing assay $(p<0.05)$ (Figure 5B). 
TRPV2 distribution: Overall Survival

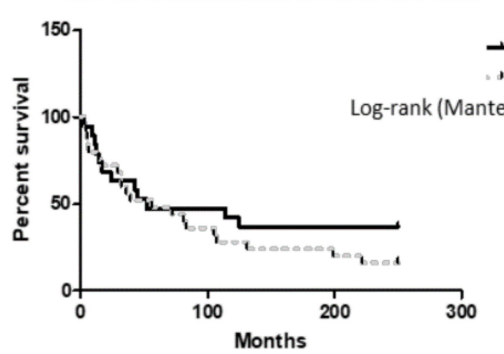

TRPV2 Distribution: Progression-Free Survival

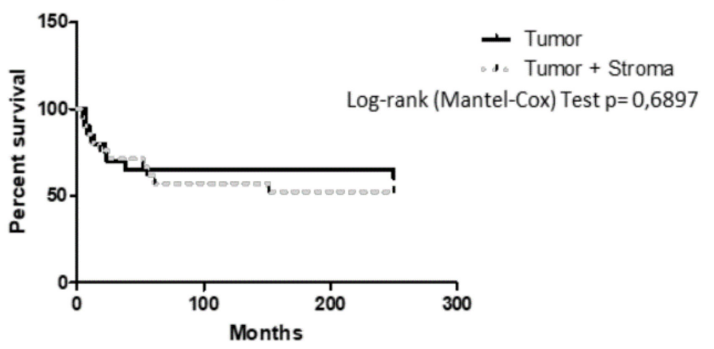

Figure 4. Survival of EC patients according to TRPV2 distribution. Kaplan-Meier survival curves showing OS and PFS of EC patients, according to TRPV2 distribution inside tumoral mass. The log-rank test with corresponding $p$ values applies to the TRPV2-tumor and TRPV2-tumor + stroma.

A

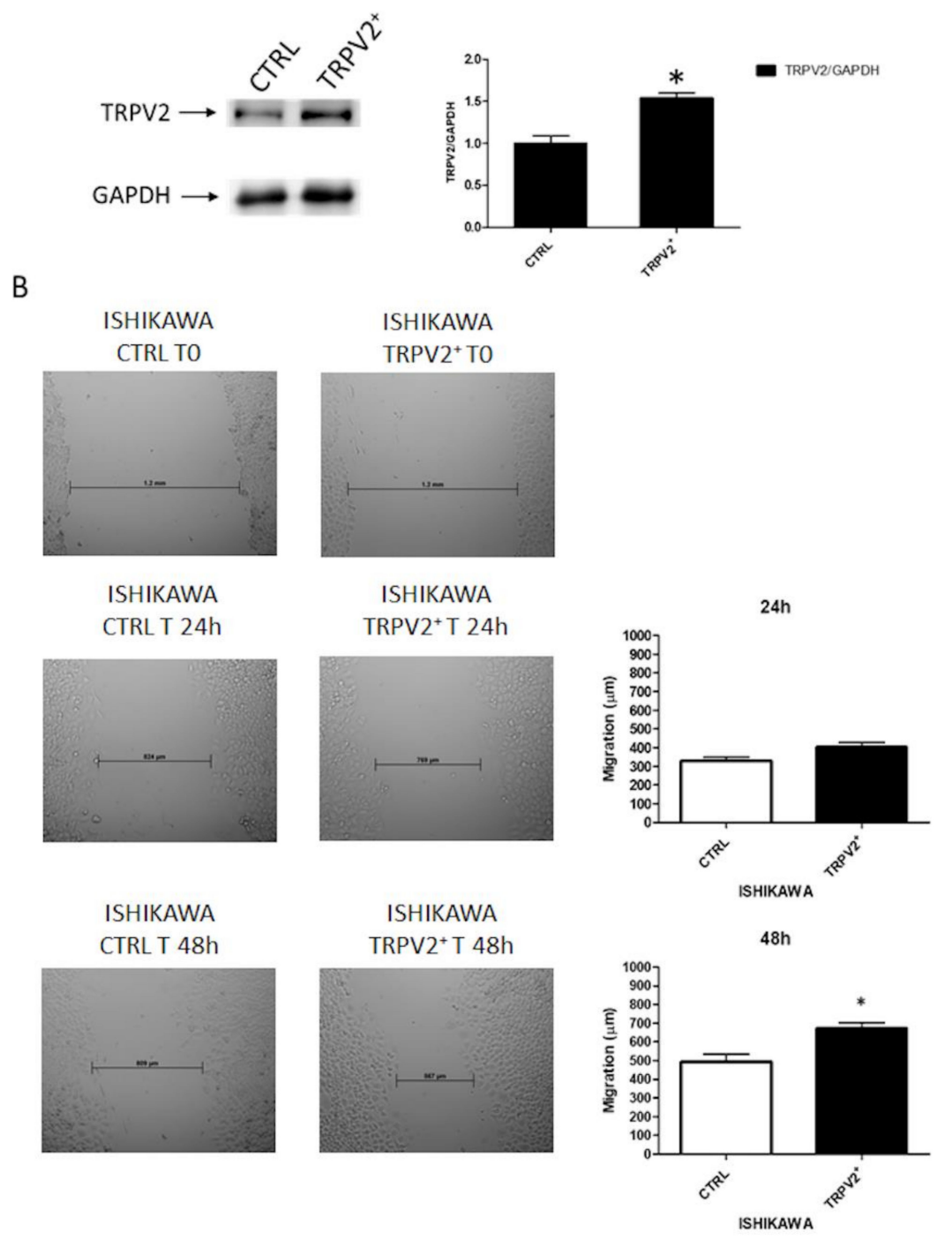

Figure 5. TRPV2 over-expression enhanced migration of EC cells. (A) Western blot analysis of TRPV2 and GAPDH protein levels in untransfected (CTRL) and TRPV2-transfected Ishikawa cells. Blots are representative of one of three separate experiments. TRPV2 densitometry values were normalized to GAPDH used as loading control and normalized. Densitometric values shown are the mean \pm SD of three separate experiments. ${ }^{*} p<0.05$ vs. control cells. (B) Wound-healing assays for Ishikawa cells after TRPV2 over-expression. All experiments were repeated three times. Data are presented as the mean \pm SD. ${ }^{*} p<0.05$ vs. control. 
Additionally, since Protein kinase B (PKB), also known as Akt, pathway is involved in supporting several pro-tumoral processes, to assess the potential role of TRPV2 in regulating cancer cell migration, modulation of AKT/PKB pathway was evaluated through Western blot analysis.

Indeed, AKT phosphorylated form was significantly increased in TRPV2 ${ }^{+}$cells $(p<0.001)$ supporting the hypothesis that TRPV2 expression increases cancer aggressiveness (Figure 6).

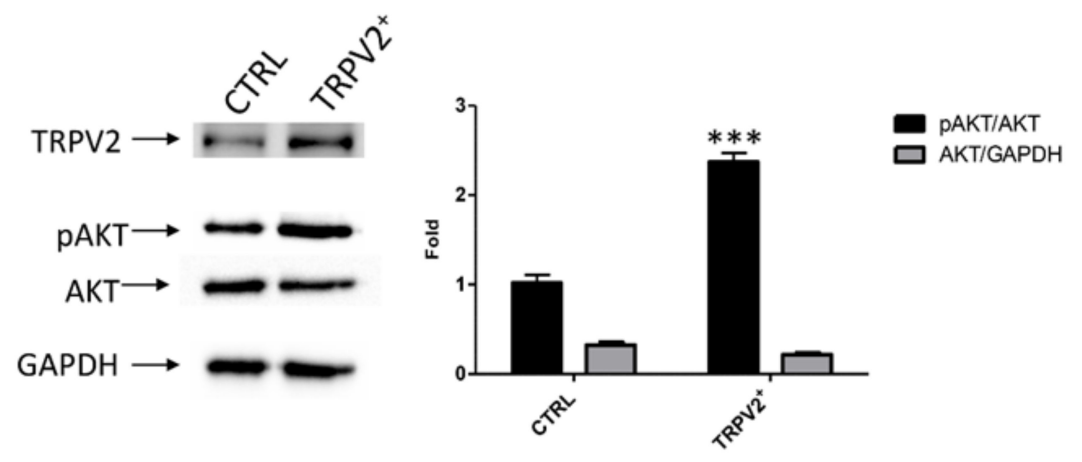

Figure 6. TRPV2 over-expression increased phosporilated form of AKT (pAKT) in EC cells. Representative Western blot analysis of pAKT(Ser473), AKT and GAPDH protein levels in TRPV2 ${ }^{+}$ cells. The pAKT(Ser473) protein levels were determined with respect to AKT levels. AKT densitometry values were normalized to GAPDH used as loading control. Densitometric values shown are the mean \pm SD of three separate experiments. ${ }^{* * *} p<0.001$ vs. control cells.

\subsection{TRPV2 Expression Influenced the Effect of Chemotherapeutic Drugs}

Untransfected and TRPV2 ${ }^{+}$Ishikawa cells were treated with CIS and DOX (from $0.0064 \mu \mathrm{g} / \mathrm{mL}$ to $100 \mu \mathrm{g} / \mathrm{mL}$ ), and PAC (from $0.00025 \mu \mathrm{g} / \mathrm{mL}$ to $4 \mu \mathrm{g} / \mathrm{mL}$ ) for $72 \mathrm{~h}$. Results showed that TRPV2 expression increased chemo-sensitivity in Ishikawa cells for CIS $(p<0.05)$, while it did not particularly modulate the effect of DOX and PAC (Figure 7).
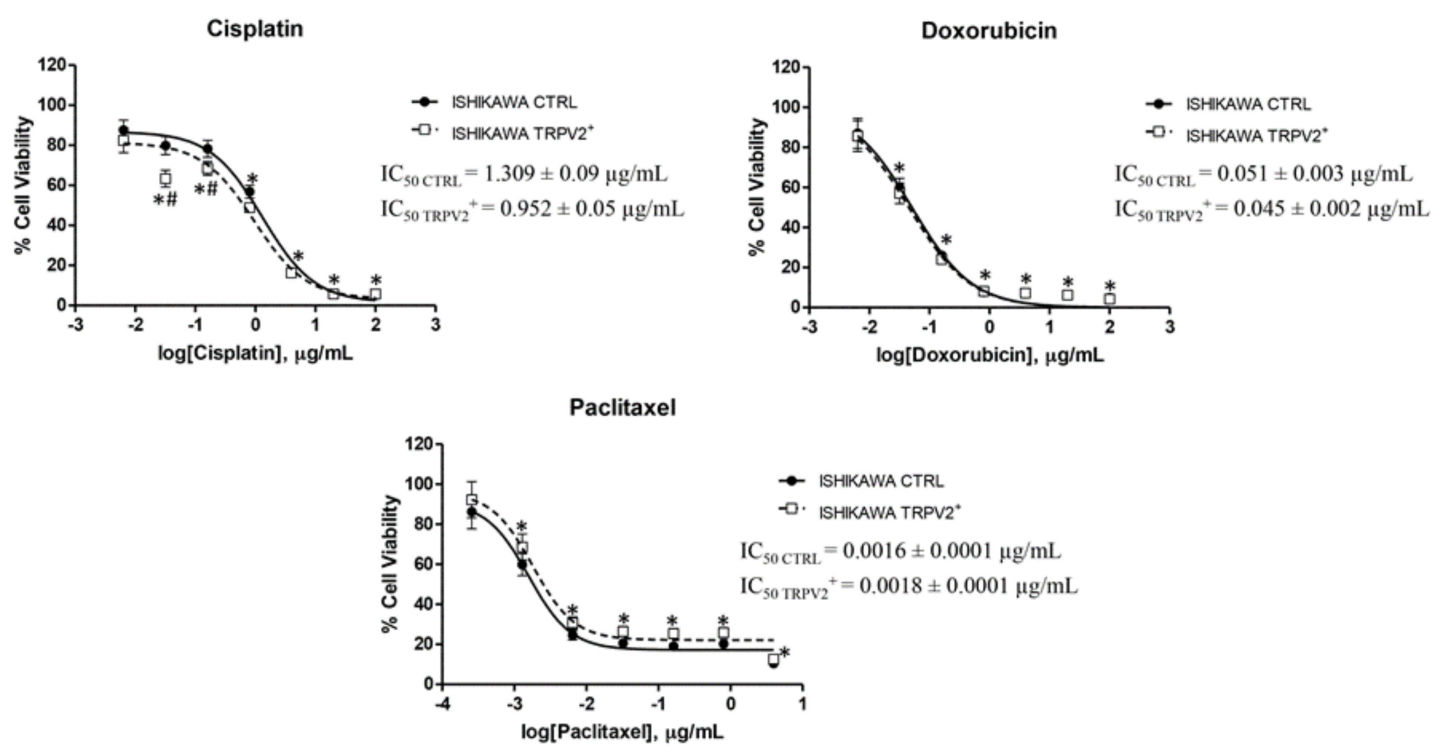

Figure 7. TRPV2 over-expression enhanced CIS sensitivity. Untransfected and TRPV2 ${ }^{+}$cells were treated for $72 \mathrm{~h}$ with different concentrations of CIS, DOX (up to $100 \mu \mathrm{g} / \mathrm{mL}$ ) and PAC (up to $4 \mu \mathrm{g} / \mathrm{mL}$ ). Data shown are expressed as mean \pm SD of three separate experiments. ${ }^{*} p<0.05$ treated vs. vehicle, $\# p<0.05$ TRPV2 $^{+}$vs. control. 


\subsection{CBD Induced Cytotoxicity in EC Cell Lines in Single and Daily Administration}

The effect of CBD, a TRPV ligand, in reducing cell viability was evaluated in EC cell lines in single and daily administration, washing cells with fresh medium in daily treatment. Cells were treated for $72 \mathrm{~h}$ with CBD (up to $15.72 \mu \mathrm{g} / \mathrm{mL}$ ) and percentage of cell viability was evaluated by a cell viability MTT assay (Figure 8). The results showed a dose-dependent CBD effect in all EC cell lines, with $\mathrm{IC}_{50}$ values reported in Table 2. Additionally, daily administration induces higher cytotoxicity when compared with CBD single administration (Figure 8, Table 2). So, we decided to work with the doses of 3.92, 7.85 and $15.72 \mu \mathrm{g} / \mathrm{mL}$, according with the $\mathrm{IC}_{50}$ of each EC cell line, in daily administration.
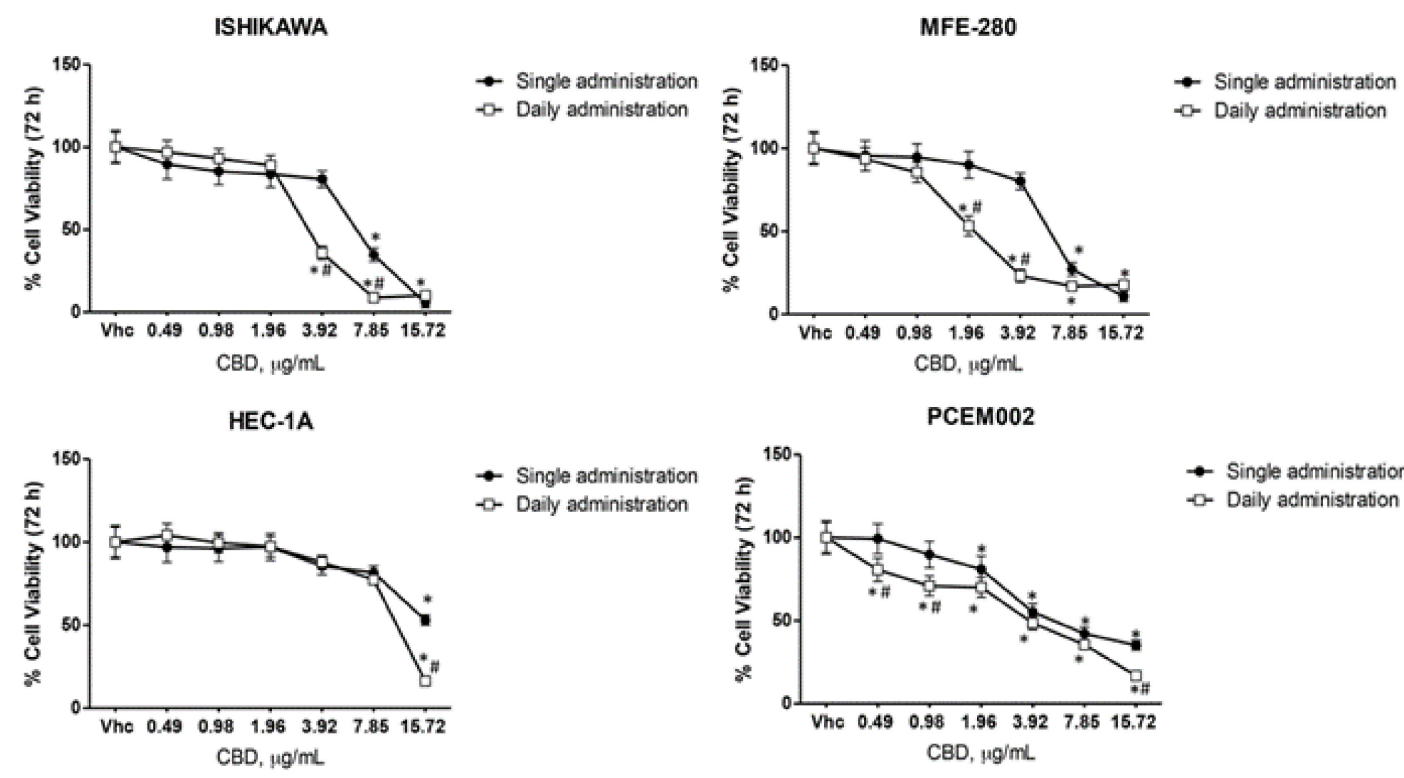

- Single administration - Daily administration

PCEM004A
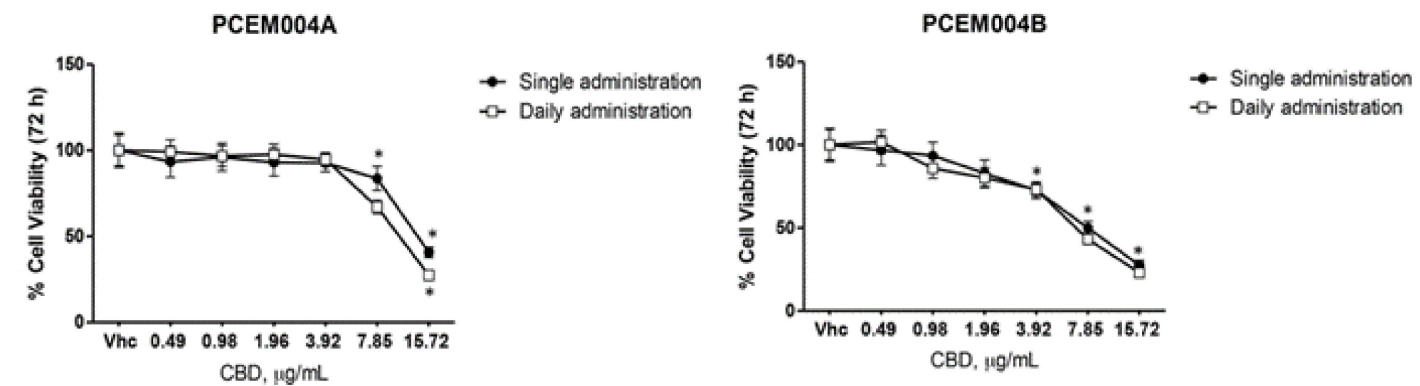

Figure 8. CBD induced cytotoxicity in EC cell lines. Cell viability was determined by MTT assay. Ishikawa, MFE-280, HEC-1a, PCEM002, PCEM004a and PCEM004b cells were treated for $72 \mathrm{~h}$ with different concentrations of CBD (up to $15.72 \mu \mathrm{g} / \mathrm{mL}$ ). Data shown are expressed as mean $\pm \mathrm{SD}$ of three separate experiments. ${ }^{*} p<0.05$ treated vs. vehicle, $\# p<0.05$ daily vs. single administration.

Table 2. $\mathrm{CBD} \mathrm{IC}_{50}$ values in $\mathrm{EC}$ cell lines expressed as mean $\pm \mathrm{SD}$ of three separate experiments.

\begin{tabular}{cccc}
\hline \multicolumn{4}{c}{ IC $_{50}$ CBD $\mu \mathrm{g} / \mathbf{m L}$} \\
\hline & Single Administration & Daily Administration & $p$ Value \\
\hline Ishikawa & $5.89 \pm 0.4$ & $3.56 \pm 0.2$ & $* *$ \\
MFE-280 & $6.33 \pm 0.5$ & $2.39 \pm 0.1$ & $* *$ \\
HEC-1A & $23.38 \pm 0.8$ & $13.16 \pm 0.6$ & $*$ \\
PCEM002 & $6.58 \pm 0.2$ & $3.59 \pm 0.1$ & $*$ \\
PCEM004a & $20.02 \pm 0.7$ & $14.01 \pm 0.6$ & $*$ \\
PCEM004b & $8.29 \pm 0.5$ & $7.05 \pm 0.4$ & \\
\hline & $* p<0.05, * * p<0.01$, daily vs. single administration.
\end{tabular}




\subsection{CBD Induced Cell Death in Type I EC Cell Lines}

We investigated the cytotoxic effect of CBD in EC cells by Annexin V-fluorescein isothiocyanate (FITC) and Propidium Iodide (PI) staining. Each cell line was treated with an appropriate dose of $\mathrm{CBD}$ according to the $\mathrm{IC}_{50}$ in daily administration, up to $72 \mathrm{~h}$. Then, fluorescence was analyzed by flow cytometry. The results evidenced that $\mathrm{CBD}$ treatment increased the percentage of Annexin $\mathrm{V}^{+}$or Annexin $\mathrm{V}^{+} / \mathrm{PI}^{+}$cells in MFE-280, HEC-1a and in primary PCEM002 cell lines, indicating apoptotic cell death, but only $\mathrm{PI}^{+}$cells were detected in Ishikawa cell line, indicating a necrotic cell death (Figure 9). In PCEM004a and PCEM004b, CBD treatment resulted in a non-significant increase of PI and/or Annexin $\mathrm{V}^{*}$ cells. This result was not comparable with cell viability reduction demonstrated by MTT. For this reason, we decided to deepen investigate CBD effects in PCEM004a and PCEM004b mixed type EC cells.

\subsection{CBD Induced Cell Cycle Arrest and Autophagy in Mixed Type I/II EC Cell Lines}

In order to investigate the reduction in cell viability in mixed type I/II PCEM004a and PCEM004b, the role of CBD treatment in regulating cell cycle was evaluated. The results showed that CBD was able to induce cell accumulation in the G1 phase (Figure 10). These data evidenced that CBD-reduced cell viability in PCEM004 cells, was partially due to cell cycle inhibition.

Since it has been demonstrated that CBD is able to induce autophagy in cancer [4], we investigated whether the reduction of cell viability and the G1 cell accumulation by CBD treatment was due to an autophagic process in mixed type I/II primary cell lines. We analyzed the conversion of the soluble form of LC3 (LC3-I) to the lipidated and autophagosome-associated form (LC3-II), marker of autophagy activation after $48 \mathrm{~h}$ and $72 \mathrm{~h}$ of daily treatment, using Western blot analysis. We found that CBD induced a strong increase of the cleaved LC3-II form, especially in PCEM004a after $72 \mathrm{~h}$ (Figure 11A).

To confirm autophagy activation, we used acridine orange dye, which accumulates in acidic vesicular organelles, considered as an indicative marker of autophagy. These organelles emit bright red fluorescence, the intensity of which is proportional to the degree of the acidity and the volume of these structures, thus we assessed this fluorescence at the microscope. As depicted in Figure 11B, CBD treatment promoted acidic vesicular organelles formation after $48 \mathrm{~h}$, especially at $7.85 \mu \mathrm{g} / \mathrm{mL}$, in PCEM004 cell lines.

\subsection{CBD Inhibited Migratory Ability of EC Cells}

To further investigate anti-tumor effects of CBD, we treated Ishikawa, PCEM004a and PCEM004b cells with CBD for $24 \mathrm{~h}$ and then measured cell migration. The results showed that CBD was able to reduce migratory capacity of Ishikawa cells compared with vehicle-treated cells in a dose-dependent manner, with a significant effect at $7.85 \mu \mathrm{g} / \mathrm{mL}(p<0.05)$ (Figure 12).

In both PCEM004 cells, CBD strongly reduced migratory ability of EC cells, already from the lowest doses of $3.92 \mu \mathrm{g} / \mathrm{mL}$, up to inhibiting completely the migration at $7.85 \mu \mathrm{g} / \mathrm{mL}(p<0.001)$ (Figure 13, Figure S2).

\subsection{CBD Increased the Effect of Chemotherapeutic Drugs Used for EC Treatment}

The effect of CBD combined with chemotherapeutic drugs was evaluated in TRPV2-transfected Ishikawa cells, compared with untransfected cells. Both models were exposed to CBD at $3.92 \mu \mathrm{g} / \mathrm{mL}$, in combination with two non-cytotoxic doses of each chemotherapeutic drug: CIS 0.25 and $0.5 \mu \mathrm{g} / \mathrm{mL}$, DOX 0.015 and $0.03 \mu \mathrm{g} / \mathrm{mL}$, PAC 0.0015 and $0.003 \mu \mathrm{g} / \mathrm{mL}$ for $72 \mathrm{~h}$. Chemotherapeutic drugs were administered once, while CBD was administered daily. The combined treatment induced an increased level of cytotoxicity, as compared with either CBD or all chemotherapeutic drugs alone, in both models (Figure 14). Additionally, the combination of chemotherapeutic drug and CBD, except for PAC, was significantly more cytotoxic in TRPV2-transfected cells (Figure 14). These results suggest that CBD 
enhanced the effect of chemotherapeutic drugs, used at lowest doses, in a TRPV2-dependent manner, thus supporting the feasible use of CBD as an adjuvant in the treatment of human EC.
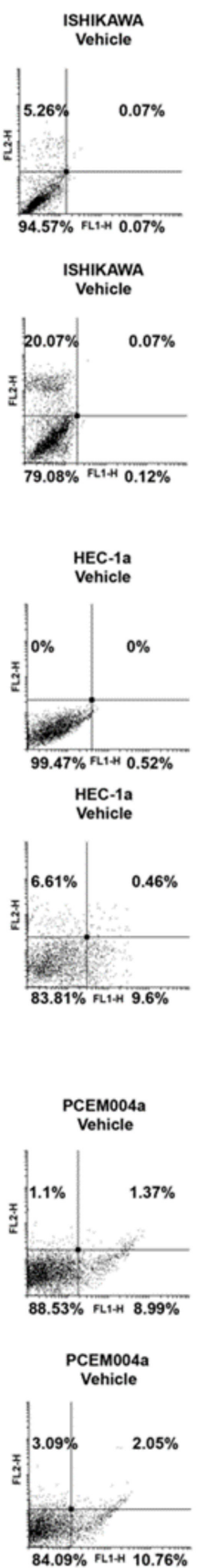
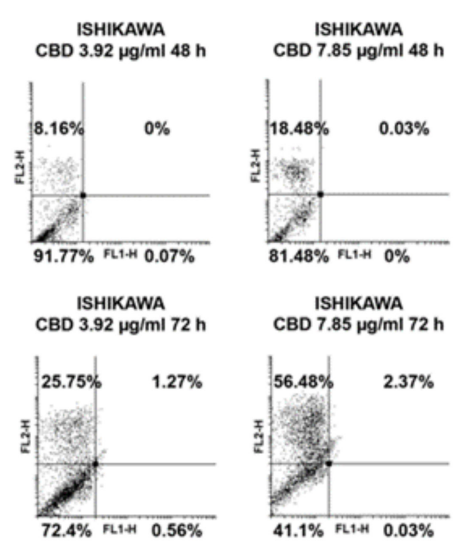

ISHIKAWA
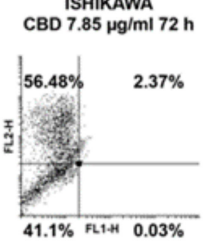

HEC-1a
CBD $7.85 \mu \mathrm{g} / \mathrm{ml} 48 \mathrm{~h}$

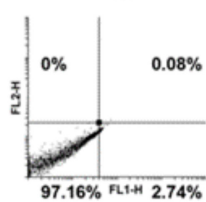

HEC-1a
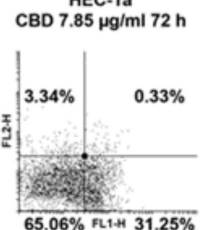

$65.06 \%$ FL $1+31.25 \%$
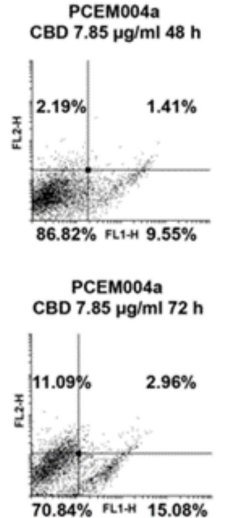

HEC-1a

CBD $15.72 \mu \mathrm{g} / \mathrm{ml} 48 \mathrm{~h}$
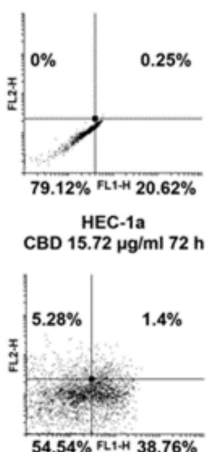
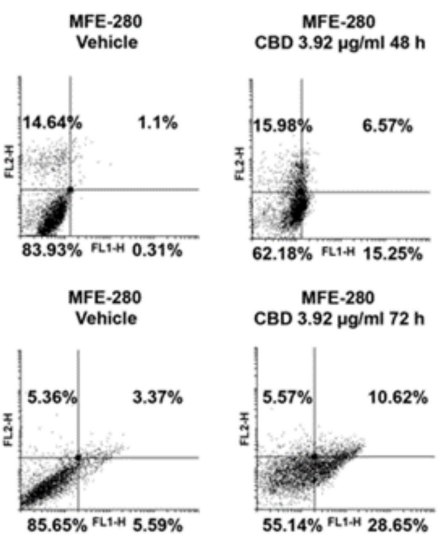

MFE-280
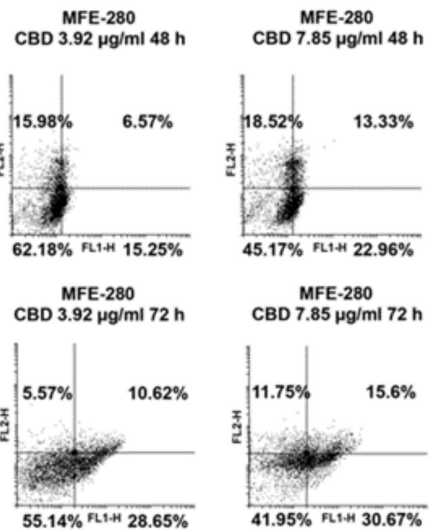

CBD $15.72 \mu \mathrm{g} / \mathrm{ml} 72$
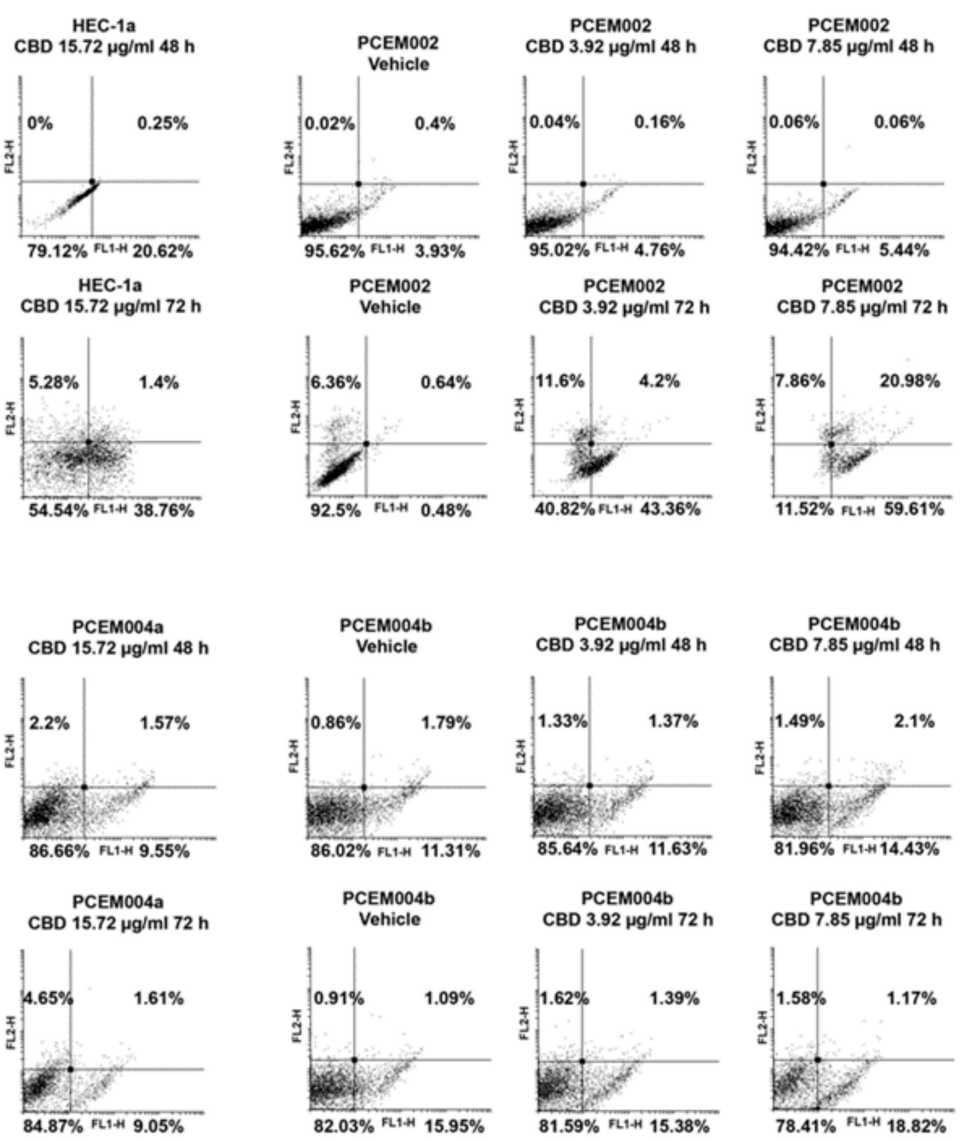
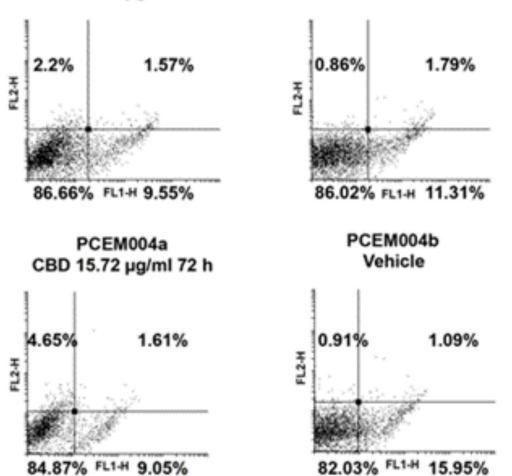

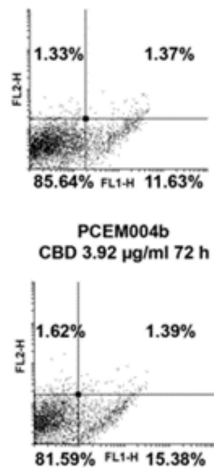

Figure 9. CBD induced cell death in EC cell lines. EC cell lines were treated with CBD for $72 \mathrm{~h}$. Flow cytometric analysis was performed by Annexin V and PI double-staining. FL1-H fluorescence signal is in $x$-axis. Data represent the percentage of PI and/or Annexin $\mathrm{V}^{+}$cells and are representative of one of three separate experiments. 

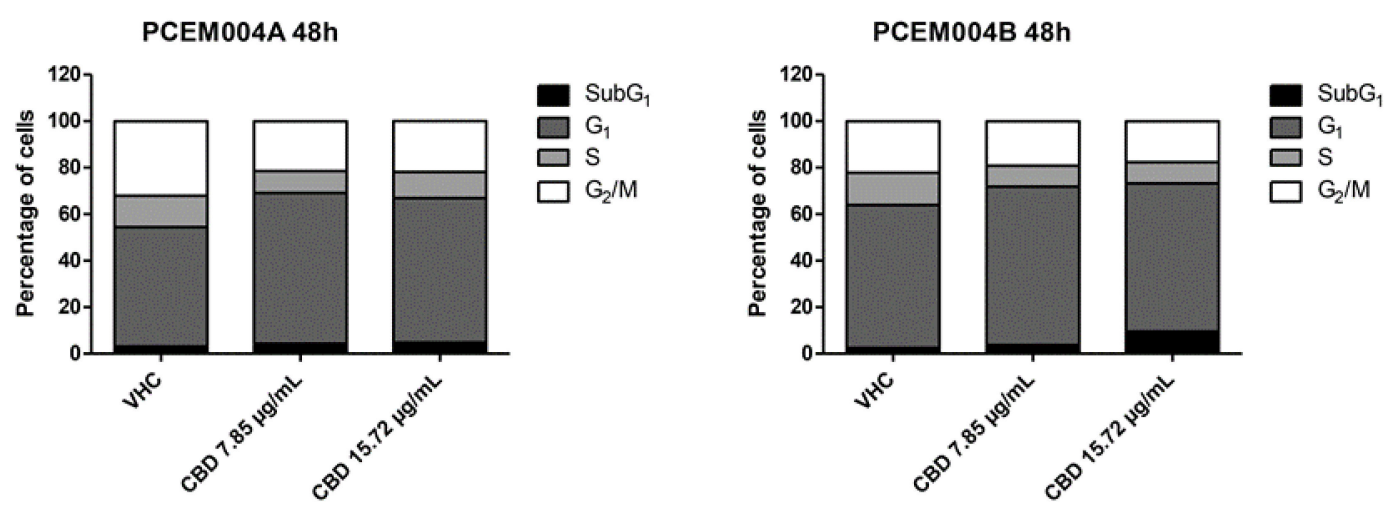

Figure 10. CBD induced cell cycle arrest in PCEM004 EC cell lines. PCEM004a and PCEM004b EC cell lines were treated with CBD up to $15.72 \mu \mathrm{g} / \mathrm{mL}$ for $48 \mathrm{~h}$. Percentage of cells are represented as histogram representations of the cell cycle phases in the EC cell lines and are representative of one of three separate experiments.

A

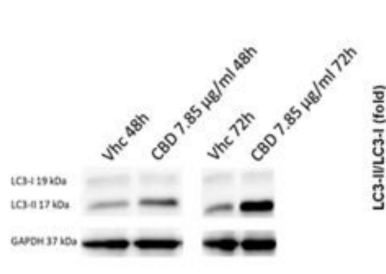

PCEM004A

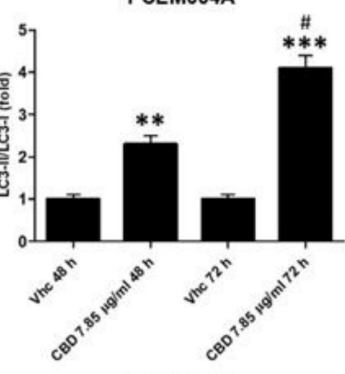

PCEM004B

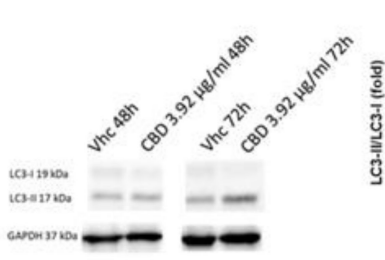

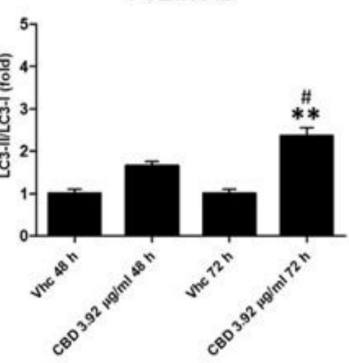

B
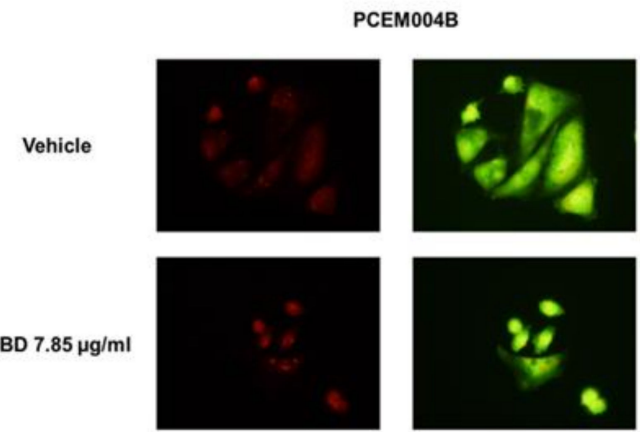

CBD $15.72 \mu \mathrm{g} / \mathrm{ml}$
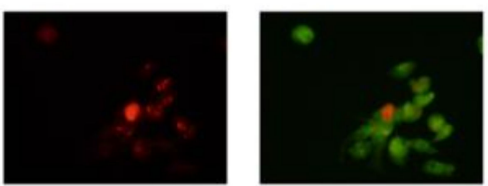

Figure 11. CBD induced autophagy in mixed type I/II EC cell lines. (A) Western blot analysis and densitometric quantification of LC3 protein levels PCEM004a and PCEM004b mixed type EC cell lines treated for up to $72 \mathrm{~h}$ with CBD $7.85 \mu \mathrm{g} / \mathrm{mL}$ and $3.92 \mu \mathrm{g} / \mathrm{mL}$, respectively. Densitometric values, shown as the mean $\pm \mathrm{SD}$, were normalized to GAPDH used as loading control. Blots are representative of one of three separate experiments, ${ }^{* *} p<0.01$, ${ }^{* * *} p<0.001$ treated vs. untreated cells, $\# p<0.0572 \mathrm{~h}$ vs. $48 \mathrm{~h}$ of treatment. (B) Representative image of PCEM004a treated with CBD up to $7.85 \mu \mathrm{g} / \mathrm{mL}$ for $48 \mathrm{~h}$ and stained with acridine orange. 
T0

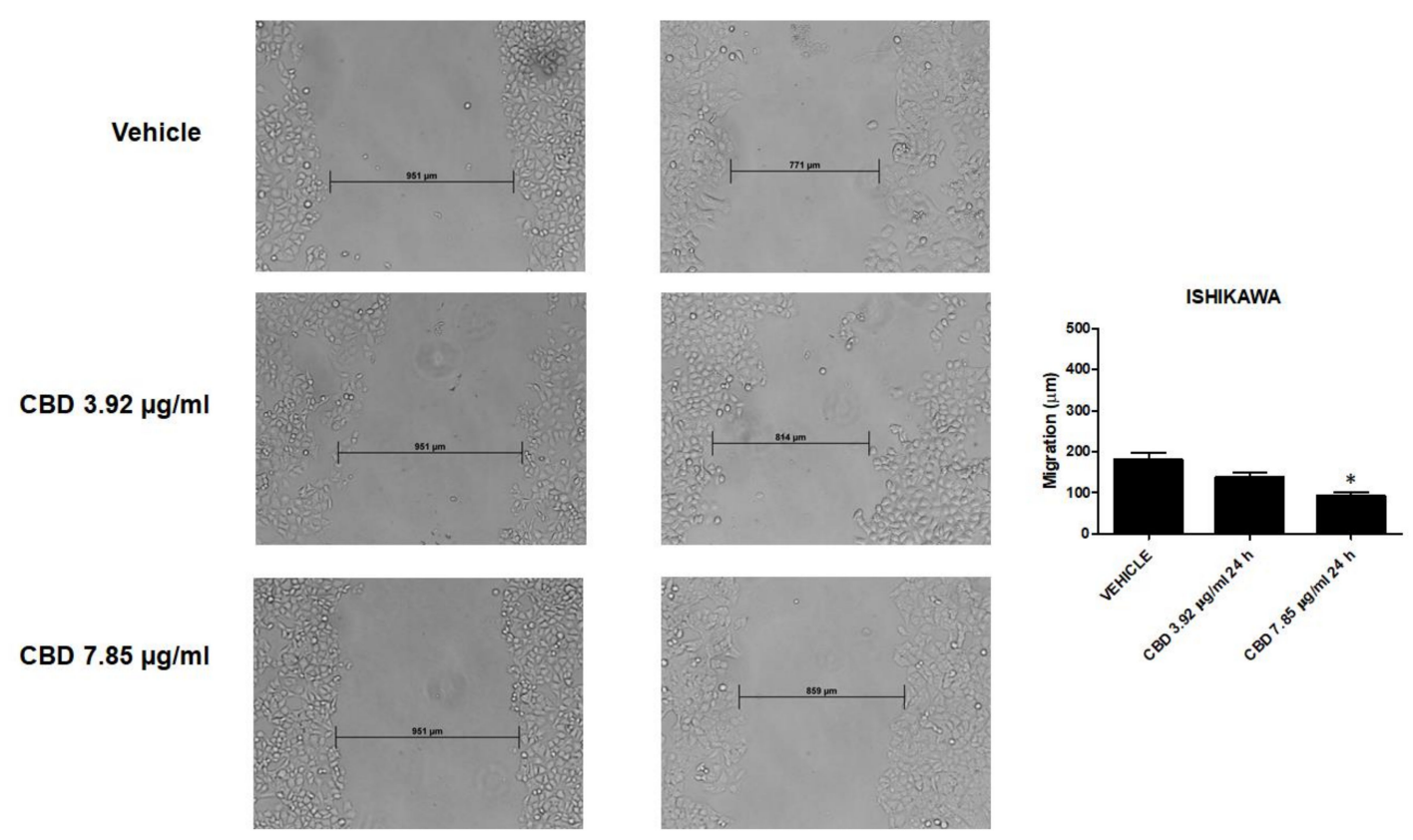

Figure 12. CBD treatment inhibited migration of Ishikawa cells. Wound-healing assays for Ishikawa cells after treatment with CBD $7.85 \mu \mathrm{g} / \mathrm{mL}$ and $3.92 \mu \mathrm{g} / \mathrm{mL}$ for $24 \mathrm{~h}$. All experiments were repeated three times and images were taken at 0 and $24 \mathrm{~h}(20 \times)$. Data are presented as the mean $\pm \mathrm{SD} .{ }^{*} p<0.05$ vs. untreated.

TO
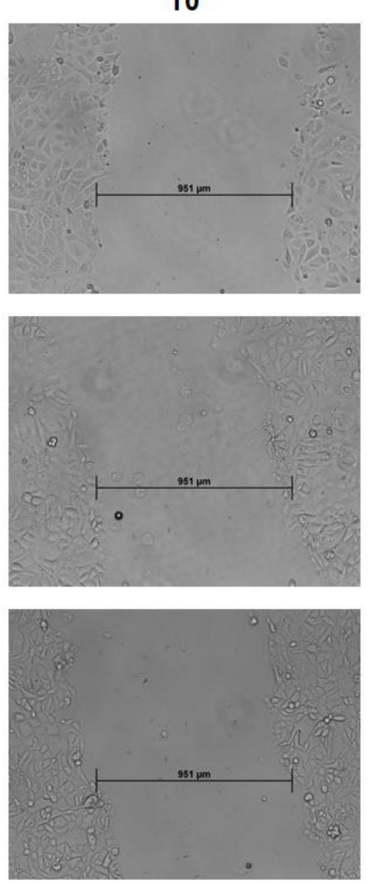

$24 \mathrm{~h}$
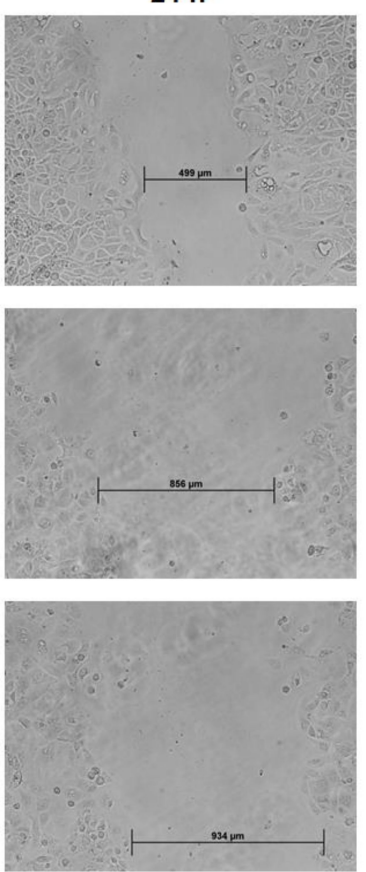

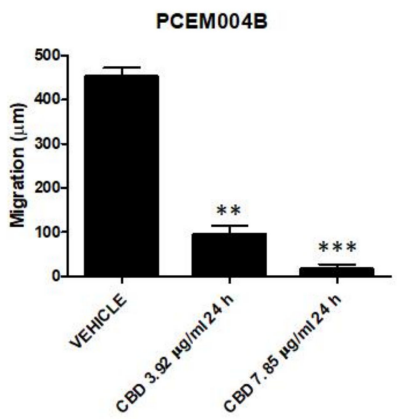

CBD $7.85 \mu \mathrm{g} / \mathrm{ml}$

Figure 13. CBD treatment inhibited migration of PCEM004b cells. Wound-healing assays for PCEM004b cells after treatment with CBD $7.85 \mu \mathrm{g} / \mathrm{mL}$ and $3.92 \mu \mathrm{g} / \mathrm{mL}$ for $24 \mathrm{~h}$. All experiments were repeated three times and images were taken at 0 and $24 \mathrm{~h}(20 \times)$. Data are presented as the mean $\pm \mathrm{SD} .{ }^{* *} p<0.01$, *** $p<0.001$ vs. untreated. 


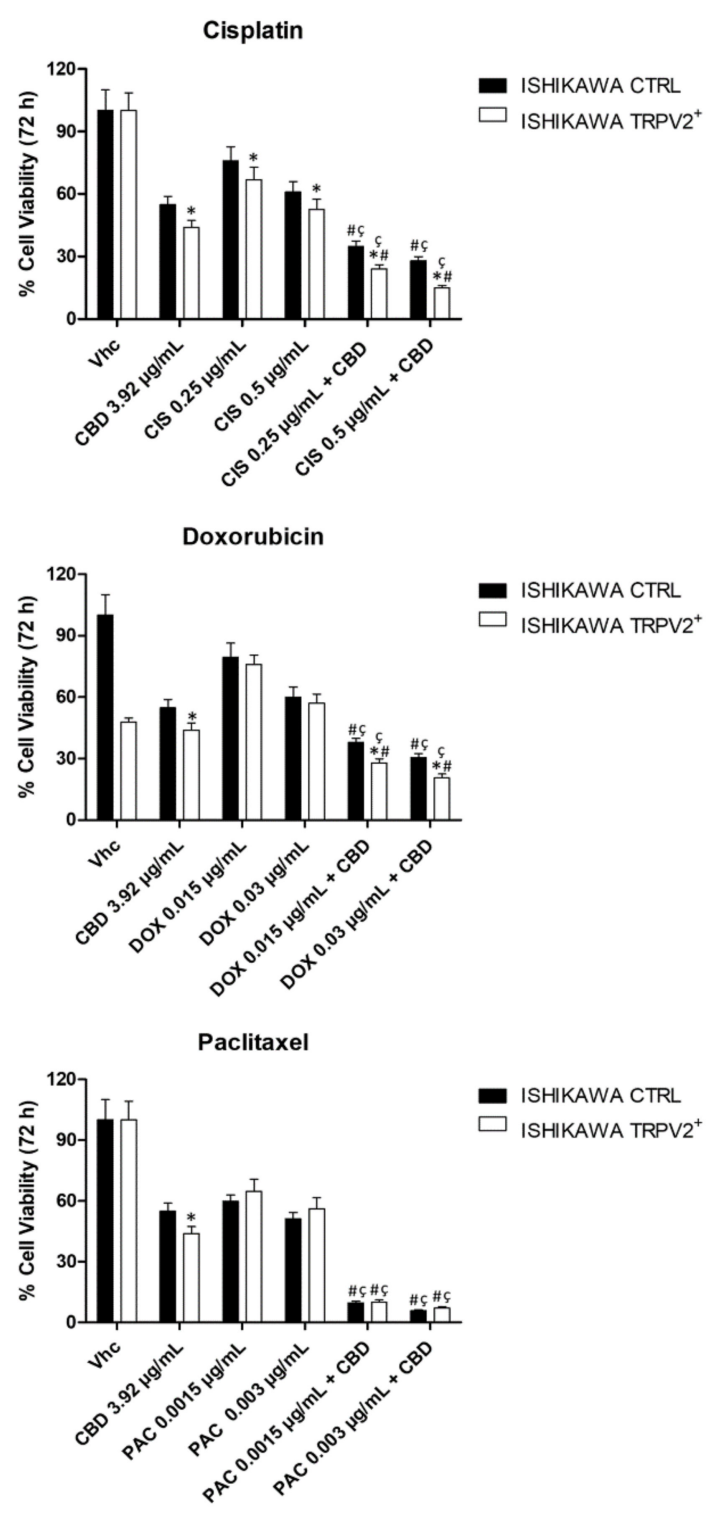

Figure 14. CBD improved chemotherapeutic drug effects in TRPV2-transfected Ishikawa cell line. Cell viability was determined in EC cell lines by MTT assay. Cells were treated for $72 \mathrm{~h}$ with CBD, alone and in combination with different doses of CIS, DOX and PAC. Data shown are expressed as mean \pm SD of three separate experiments. ${ }^{*} p<0.05 \mathrm{TRPV}^{+}$vs. control, $\# p<0.05$ vs. CBD alone, ç $p<0.05$ vs. chemotherapeutic drug alone.

\section{Discussion}

The non-endometrioid type II EC is responsible for most EC-related deaths because it is characterized by an aggressive behavior and high resistance to the common therapies. Furthermore, there are no targeted therapies approved so far for this subtype, and it is still treated in the same way as endometrioid type I EC, which is generally characterized by good prognosis and good response to therapy $[42,43]$. The relative lack of robust diagnostic/prognostic biomarkers for EC and its often-late presentation impedes the improvement of its morbidity and mortality rates. According to Taylor et al., the prognosis of EC is based exclusively on hormone receptor status that is considered not fully efficient at prognostic value [44]. This suggests that novel markers should be considered for clinical value [39]. Recently, Ayakannu et al. have shown that CB1 and CB2 receptors expression, at both transcriptional and protein levels, was reduced in human samples of both endometrioid and non-endometrioid EC [39]. These results are in contrast with previous studies of Guida et al. [45] and Fonseca et al. [24], 
in which was reported, respectively, that CB2 and CB1 are highly expressed in human samples and in two EC cell lines, type I Ishikawa and Hec50co, which expressed some characteristics of type II EC. Our data obtained from TCGA are in accordance with Ayakannu et al.'s findings. The reason for this could be related to methodological differences, as suggested by the authors [39]. Regarding TRPVs, Fonseca et al. demonstrated that TRPV1 was expressed in Ishikawa and Hec50co cell lines, but no data were provided for another CBD target, such as TRPV2 [24].

Herein we show that TRPV2 expression augmented with the increasing of a non-endometrioid component and its expression in human EC samples of type II and mixed type was associated with a reduced PFS. Additionally, its expression increases with malignancy, according to FIGO stage. Previously, it has been demonstrated that TRPV2 expression correlates with worse OS and PFS for triple negative breast cancer [13], esophageal squamous cell carcinoma [46], MM [47] and gastric cancer [48]. Furthermore, its expression increases with increasing of tumor stage in urothelial cancer [34], gastric cancer [48] and esophageal squamous cell carcinoma [46]. TRPV2-mediated signaling pathways modulate some pathological processes in cancer [30]. Indeed, previous evidences show that inactivation of TRPV2-mediated signals in cancer leads to an uncontrolled proliferation and cell death-resistance, and that TRPV2 activation increases migratory capability and invasiveness of cancer cells [49]. TRPV2 enhances migration process of prostate cancer cells through a TRPV2-mediated calcium influx, via Gq/Go, phosphatidylinositol-3,4 kinase (PI3,4K) signaling and translocation of TRPV2 from endosome to the plasma membrane [34]. Here, we show that TRPV2 ${ }^{+}$EC cells have a high migratory ability, and its expression induces an increase of pAKT/AKT ratio, supporting the activation of PI3K pathway in TRPV2 ${ }^{+}$cells that leads to high migratory ability and survival. These data could support the evidence that high expression of TRPV2 in patients correlates with shorter PFS.

High TRPV2 expression or its activation by CBD was associated to enhance drug-uptake with a resulting increase of chemosensitivity and cytotoxic effects on cancer cells in GBM and triple negative breast cancer $[13,25,50]$. Indeed, it has been demonstrated that DOX permeates directly through TRPV2 pore channel, in TRPV2-transfected GBM cells [25]. Herein, we show that, treating TRPV2 ${ }^{+}$ EC cells with CIS, DOX or PAC, the presence of TRPV2 expression increased CIS cytotoxic effect, suggesting that TRPV2 can influence chemo-sensitivity to this drug. Compared with GBM cells, Ishikawa cells are more sensitive to DOX ( $\sim 50$-fold), and its increase in uptake and cytotoxicity TRPV2-dependent, as previously described in GBM [25], are not appreciable in our model. Moreover, as in MM and breast cancer cells $[19,25,51]$, combination of CBD and chemotherapeutic drug, dispays an increased cytotoxic effect compared with chemotherapeutic drug or CBD alone, especially in TRPV2-transfected cells, suggesting that this effect could be partially due to TRPV2 activation by CBD. Overall, TRPV2 expression in EC could be potentially considered as a marker to optimize the therapy.

Up to now, the antitumoral effect of cannabinoids in different human cancer cell lines and in vivo preclinical models has been demonstrated [3-24]. In GBM, CBD alone and in combination with THC, induced a cell viability reduction and apoptosis in vitro and in vivo [25,52,53]. Regarding lung cancer, $\mathrm{CBD}$ induced apoptotic cell death in in vitro model and in primary cells derived from patients; moreover, it induces tumor regression in in vivo model [7]. In breast cancer, CBD inhibited AKT and mTOR signaling inducing autophagic cell death [12]. In MM, CBD was able to reduce cell proliferation and induce a necrotic cell death [19]. Our results evidence as CBD was able to reduce cell viability in EC cell lines, inducing predominantly apoptotic cell death. These data are in agreement with previous findings related to the efficacy of CBD as anticancer molecule.

Recently, Fonseca et al. published preliminary data regarding anticancer effect of eCBs, THC and $\mathrm{CBD}$ in Ishikawa and Hec50co cell lines. They found that a significant reduction in cell viability was observed with eCBs and CBD in both EC cell types, while, with THC treatment $(0.01-25 \mu \mathrm{M})$, no changes were observed. In Ishikawa cells, CBD at $5 \mu \mathrm{M}(1.57 \mu \mathrm{g} / \mathrm{mL})$ induced chromatin condensation, increased levels of ROS/RNS, decreasing mitochondrial membrane potential, which results in an apoptotic cell death [24]. These data are quite in contrast with our findings. Indeed, CBD induces apoptotic cell death in MFE-280, HEC-1a, and PCEM002 but in Ishikawa cell line, CBD treatment 
results in increased $\mathrm{PI}^{+} /$Annexin $^{-}$cell population. The main difference is probably related with CBD concentration used and treatment protocol. Indeed, in our study, cells were treated daily and a necrotic cell death in Ishikawa cell line was detected with a higher concentration of CBD compared with Fonseca et al.'s experiments. Additionally, our data demonstrate that CBD treatments leads to cell cycle arrest and autophagic process in the mixed type I/II cells. Autophagy is an intracellular process by which cellular material is delivered to lysosomes for degradation allowing self-renewal and survival but, in cancer, autophagy has opposing context-dependent roles and then, autophagy stimulation or inhibition has been proposed as cancer therapy [54]. It has been found that CBD is able to induce autophagy, as demonstrated in breast cancer, colon rectal cancer and glioma stem-like cells (GSC), leading to cell death, increased chemosensitivity and inhibition of GSCs' proliferation and clonogenic capability $[4,12,55]$. These data support our results in which CBD induced an autophagic process in the most aggressive and resistant mixed type cells, which express TRPV2 channel, thus, arrested cell proliferation and migration. However, since it is known that CBD acts both in a dependent (D)- and independent (ID)-receptors mechanisms (RMs) [26-28], our results support that CBD effects can be obtained also in TRPV2-low expressing EC cells.

\section{Materials and Methods}

\subsection{The Cancer Genome Atlas (TCGA) and cBioportal Database Analysis}

The cBioPortal for Cancer Genomics is an open-access downloaded bio-database, providing visualization and analyzing tools for large-scale cancer genomics data sets (http://cbioportal.org). Analysis of 506 sequenced EC samples from this database (PanCancer Atlas) was performed in order to evaluate PD-Ls expression, following the online instructions of cBioPortal database for Genetic Alteration, Mutation level, Clinical Attribute, and mRNA expression. Briefly, the cancer-specific TCGA datasets were selected followed by selection of mRNA expression z-scores relative to all samples (log RNA Seq V2 RSEM) and, CB1, CB2, TRPV1 and TRPV2 gene symbols, in the specified columns. On submitting the query, the software shows all types of genomic alterations including somatic mutations, copy number change, and mRNA expression, in a concise graphical summary called oncoprint. Then, data were downloaded, and mRNA expression values were analyzed with GraphPad (GraphPad Software, San Diego, CA, USA).

\subsection{Endometrial Cancer Cell Lines}

Ishikawa and MFE-280 cells, respectively well and poorly differentiated type I cell lines, were purchased from Sigma-Aldrich (Milan, Italy). Ishikawa cells were grown in EMEM medium (Lonza, Milan, Italy), supplemented with 5\% fetal bovine serum (FBS), $2 \mathrm{mM} / \mathrm{L}$ glutamine, $100 \mathrm{IU} / \mathrm{mL}$ penicillin, $100 \mathrm{mg}$ streptomycin. MFE-280 cells were grown in EMEM medium (Lonza, Milan, Italy), supplemented with $10 \%$ fetal bovine serum (FBS), $2 \mathrm{mM} / \mathrm{L}$ glutamine, $100 \mathrm{IU} / \mathrm{mL}$ penicillin, $100 \mathrm{mg}$ streptomycin. HEC-1A and the primary endometrial cancer cell lines PCEM002, PCEM004a, PCEM004b were kindly provided by Dr. Fréderic Amant (Department of Oncology, KU Leuven, Leuven, Belgium). HEC-1A moderately differentiated type I cells were grown in McCoy's Medium (Lonza, Milan, Italy), supplemented with 10\% FBS, $100 \mathrm{IU} / \mathrm{mL}$ penicillin, $100 \mathrm{mg}$ streptomycin, while all the primary cell lines were grown in RPMI1640, supplemented with 20\% FBS, 2 mM/L glutamine, $100 \mathrm{IU} / \mathrm{mL}$ penicillin, $100 \mathrm{mg}$ streptomycin. PCEM002 is a poorly differentiated type I cell line while PCEM004a and PCEM004b are poorly differentiated mixed type I/II cell lines. All cell lines were maintained at $37^{\circ} \mathrm{C}$ with $5 \% \mathrm{CO}_{2}$ and $95 \%$ humidity.

\subsection{Materials}

Pure CBD was supplied from ENECTA (Amsterdam, Netherlands). CBD was dissolved in ethanol. Chemotherapeutic drugs CIS, DOX and PAC were purchased from Sigma-Aldrich (Milan, Italy). 


\subsection{RNA Isolation, Reverse Transcription and Quantitative Real-Time PCR}

Total RNA from cell lines was extracted with the RNeasy Mini Kit (Qiagen, Milan, Italy), and cDNA was synthesized using the iScript Advanced cDNA Synthesis Kit for RT-qPCR (Bio-Rad, Milan, Italy) according to manufacturer's protocol. Quantitative real-time polymerase chain reactions (qRT-PCR) were performed with QuantiTect Primer Assays for human transient receptor potential vanilloid receptor 2 cation channel (TRPV2) and glyceraldehydes-3-phosphate dehydrogenase (GAPDH) (Qiagen, Milan, Italy), using the iQ5 Multicolor Real-Time PCR Detection System (Bio-Rad, Milan, Italy). The PCR parameters were $10 \mathrm{~min}$ at $95^{\circ} \mathrm{C}$ followed by 40 cycles at $95^{\circ} \mathrm{C}$ for $15 \mathrm{~s}$ and $60^{\circ} \mathrm{C}$ for $40 \mathrm{~s}$. The relative amount of target mRNA was calculated by the $2^{-\triangle \triangle C t}$ method, using GAPDH as a housekeeping gene. All samples were assayed in triplicates in the same plate. Measurement of GAPDH levels was used to normalize mRNA contents and target gene level was calculated by the $2^{-\Delta \Delta C t}$ method.

\subsection{Western Blot Analysis}

$20 \mathrm{ug}$ of the lysates were separated on a sodium dodecyl sulfate (SDS) polyacrylamide gel, transferred onto Hybond-C extra membranes (GE Healthcare, Milan, Italy) and blocked with 5\% low-fat dry milk in PBS-Tween 20 (Sigma-Aldrich). Immunoblots were incubated with goat polyclonal anti-TRPV2 (1:300, Santa Cruz Biotechnology, Dallas, TX, USA), rabbit polyclonal anti-LC3 $(2 \mu \mathrm{g} / \mathrm{mL}$, Novus Biologicals, Centennial, CO, USA), rabbit anti-pAKT (1:1000, Cell Signaling Technology, Danvers, MA, USA), anti-AKT (1:1000, Cell Signaling Technology) and rabbit anti-glyceraldehydes-3-phosphate dehydrogenase (GAPDH, 1:8000, OriGene Technologies, Rockville, MD, USA) antibodies (Abs) for $1 \mathrm{~h}$ and then with HRP-conjugated anti-mouse or anti-rabbit secondary Abs (1:2000, Cell Signaling Technology, Danvers, MA, USA) and with HRP-conjugated anti-goat secondary Ab (1:1000, Cell Signaling Technology, Danvers, MA, USA) for $1 \mathrm{~h}$. Peroxidase activity was visualized with the LiteAblot ${ }^{\circledR}$ PLUS or TURBO (EuroClone, Milan, Italy) kit and densitometric analysis was carried out by a Chemidoc using the Quantity One software (Bio-Rad, Milan, Italy).

\subsection{Patient Samples}

After obtaining approval from the Medical Ethics Committee UZ/KU Leuven (protocol nr S61970, Dec 2018), 68 archived formalin-fixed, paraffin-embedded type II endometrial cancer samples, along with clinical data, and 15 normal tissues ( 5 of which, peritumoral tissues) were retrieved from UZ Leuven Biobank, Belgium. The sample set included 29 serous type tumors, 7 clear cell type tumors, 17 mixed type I and II, 5 peritumoral tissues from patients with type II endometrial cancer and 10 healthy endometrial tissue samples.

\subsection{Immunohistochemical Stainings}

Paraffin slides $(4 \mu \mathrm{m})$ were heated for 3 to $4 \mathrm{~h}$ at $55^{\circ} \mathrm{C}$, deparaffinized in toluene, and rinsed in ethanol. Tissues were blocked for endogenous peroxidases by incubating them $30 \mathrm{~min}$ in $0.5 \%$ $\mathrm{H}_{2} \mathrm{O}_{2}$ (Merck Millipore, Burlington, MA, USA) in methanol. For TRPV2 staining, after washing in TBS, epitopes were retrieved for $1 \mathrm{~h}$ at $90^{\circ} \mathrm{C}$ in Tris-sodium citrate $(\mathrm{pH}=6)$. Tissues were cooled down slowly in TBS. After extensive washing, tissues were blocked with $1 \%$ milk powder, $2 \%$ BSA (Sigma-Aldrich), and 0.1\% Tween-80 (Merck Millipore, Burlington, MA, USA) in TBS before antibody incubation. Blocking solutions were removed and tissues were incubated with rabbit anti-TRPV2 (VRL-1, 1:250, Thermofisher, Grand Island, NY, USA) in TBS, overnight at $4{ }^{\circ} \mathrm{C}$. After washing, slides were incubated with anti-rabbit-HRP (Dako, Glostrup, Denmark) for $30 \mathrm{~min}$ and washed again. All antibodies were visualized by $10 \mathrm{~min}$ incubation in 3,3'-diaminobenzidine (DAB, Sigma-Aldrich, Milan, Italy) $+0.015 \% \mathrm{H}_{2} \mathrm{O}_{2}$ in the dark. Nuclei were counterstained with Mayer's hematoxylin, and tissues were dehydrated in propanol, dipped in xylene, and mounted. To ensure that no staining 
was caused by aspecific binding of secondary/tertiary molecules, control slides without addition of primary antibody were used.

\subsection{Evaluation and Scoring of Immunohistochemical Stainings}

All staining were evaluated semi-quantitatively, using an Allred scoring system that takes into account both intensity $(0=$ absent, $1=$ weak, $2=$ moderate, and $3=$ strong $)$ and percentage of stained cells $(0=$ absent, $1=$ less than $1 \%, 2=1-10 \%, 3=11-33 \%, 4=34-66 \%$, and $5=67-100 \%$ ) [56]. Both scores were added to obtain a maximum score of 8 . Tissues were considered with a high expression at a cut-off score of 6 , corresponding to strong positivity in $\geq 11 \%$ of cells, moderate positivity in $\geq 34 \%$ of cells, or weak staining in $\geq 67 \%$ of cells. This cut-off was deemed clinically relevant for therapeutic applications, as a targeted therapy would most likely be effective when a sufficient number of cells express the target. Tissues with a value between 4 and 5 were classified as moderate. Photographs of representative cases were taken using the Axioskop microscope (MRc5, Zeiss, Oberkochen, Germany) and the ZEN 2.0 software.

\subsection{Cell Transfection}

Ishikawa cells were plated at density $3 \times 10^{4}$ cells/mL. After $12 \mathrm{~h}$ incubation, transfection was performed with $3 \mu \mathrm{l} / \mathrm{mL}$ of the reagent TurboFectin Transfection Reagent (OriGene Technologies, Rockville, MD, USA) and $1 \mu \mathrm{g} / \mathrm{mL}$ of pCMV empty (pCMV6) or pCMV6-TRPV2 vector (OriGene Technologies), according to manufacturer's instructions. Cells were harvested at $72 \mathrm{~h}$ post-transfection for subsequent analyses. Transfection efficiency was evaluated by Western blot analysis.

\subsection{Wound-Healing Assay}

Cells were seeded onto a twelve-well plate at density $3 \times 10^{4}$ cells $/ \mathrm{mL}$. Confluent cells were scratched using $10 \mu \mathrm{l}$ sterile pipette tips. Complete medium was replaced with fresh medium supplemented with low percentage of serum to minimize cell proliferation and prevent cell detachment. Images of wounded areas were taken at 0 and $24 \mathrm{~h}$ for wild-type cells, treated with CBD at 3.92 and $7.85 \mu \mathrm{g} / \mathrm{mL}$. Additionally, migration was evaluated in non-transfected and transfected cells for up $48 \mathrm{~h}$. Images acquisition was carried out by a LeitzFluovert FU (Leica Microsystems, Wetzlar, Germany) microscope. Remaining wound areas were determined using NIH Image J software (Research Services Branch (RSB), National Institutes of Health (NIH), Bethesda, MD, USA) for calculation of the percentage of wound closure. Analyses were performed in triplicate.

\subsection{3-[4,5-Dimethylthiazol-2-Yl]-2,5 Diphenyl Tetrazolium Bromide (MTT) Assay}

Cell lines $\left(3 \times 10^{4}\right.$ cells $\left./ \mathrm{mL}\right)$ were seeded in 96-well plates, in a final volume of $100 \mu \mathrm{L} / \mathrm{well}$. After one day of incubation, CBD was added in single or daily administration for $72 \mathrm{~h}$, after washing with fresh medium, while chemo-drugs were single administered. At least six replicates were used for each treatment. At the indicated time point, cell viability was assessed by adding $0.8 \mathrm{mg} / \mathrm{mL}$ of 3-[4,5-dimethylthiazol-2-yl]-2,5 diphenyl tetrazolium bromide (MTT) (Sigma-Aldrich, Milan, Italy) to the media. The absorbance of samples, solubilized in dimethyl sulfoxide (DMSO), against a background control (medium alone) was measured at $570 \mathrm{~nm}$ using a reader microliter plate (BioTek Instruments, Winooski, VT, USA).

\subsection{Apoptosis Assays and PI Staining}

Cell death was evaluated using Annexin V-FITC Apoptosis detection Kit (eBioscience, Milan, Italy) followed by biparametric FACS analysis. Cells, at a density of $3 \times 10^{4}$ cells $/ \mathrm{mL}$, were treated with CBD for a maximum of $72 \mathrm{~h}$, in daily administration, and then incubated with Annexin V-FITC and PI, following manufacturer's protocol. Percentage of positive cells determined over 10,000 events 
was analyzed on a FACScan cytofluorimeter using the CellQuest software (BD Biosciences, San Jose, CA, USA).

\subsection{Cell Cycle Analysis}

Cells, at a density of $3 \times 10^{4}$ cells $/ \mathrm{mL}$, were treated with CBD for up to $48 \mathrm{~h}$, in daily administration. Cells were fixed by adding ice-cold $70 \%$ ethanol for $1 \mathrm{~h}$ and then washed with staining buffer (PBS, $2 \% \mathrm{FBS}$ and $0.01 \% \mathrm{NaN}_{3}$ ). Next, $100 \mu \mathrm{g} / \mathrm{mL}$ ribonuclease A solution (Sigma-Aldrich, Milan, Italy) was added for $30 \mathrm{~min}$ at $37^{\circ} \mathrm{C}$, stained with $20 \mu \mathrm{g} / \mathrm{mL}$ propidium iodide (PI) (Sigma-Aldrich, Milan, Italy) for $30 \mathrm{~min}$ at room temperature and finally analyzed by flow cytometry using linear amplification.

\subsection{Acridine Orange Staining}

To detect the development of acidic vesicular organelles, which are the hallmarks of autophagy, the vital staining of PCEM004 cells with acridine orange (AO, Sigma-Aldrich, Milan, Italy) was performed. The cells, at density $3 \times 10^{4}$ cells $/ \mathrm{mL}$, were seeded in 12 -well plates and were treated with CBD at 3.92 and $7.85 \mu \mathrm{g} / \mathrm{mL}$ for $48 \mathrm{~h}$. Then, cells were stained with medium containing 1 $\mu \mathrm{g} / \mathrm{mL}$ AO for $15 \mathrm{~min}$ at $37^{\circ} \mathrm{C}$, washed twice in PBS and immediately examined with Nikon Eclipse E800 fluorescence microscope and NIS-Elements 4.0 software (Nikon, Tokyo, Japan). Cytoplasm and nuclei of AO-stained cells fluoresced bright green, whereas the acidic autophagic vacuoles fluoresced bright red.

\subsection{Statistical Analysis}

The data presented represent the mean with standard deviation (SD) of at least 3 independent experiments. The statistical significance was determined by Student's t-test and by One Way-Anova and Two Way-Anova with Bonferroni's post-test; ${ }^{*} p<0.05$. Patients were divided in three groups according to high, moderate or low expression of the target protein. The Kaplan-Meier (KM) method was used for Overall Survival and Progression-Free Survival analysis. For Univariate analysis of significance (GraphPad Software, San Diego, CA, USA), long-rank test was used. ${ }^{*} p<0.05$ was considered as statistically significant. Statistical analysis of $\mathrm{IC}_{50}$ levels was performed using Prism 5.0a (GraphPad Software, San Diego, CA, USA).

\section{Conclusions}

In conclusion, TRPV2 could be considered as a new potential marker for type II EC, especially serous subtype and high-grade tumors. In addition, its expression increased EC aggressiveness, enhancing migratory capacity through AKT/mTOR activation. CBD, a TRPV2 ligand, might be a potentially useful therapeutic option as adjuvant therapy to increase the efficacy of chemotherapeutic drugs to reduce cancer cell spreading.

Supplementary Materials: The following are available online at http://www.mdpi.com/1422-0067/21/15/5409/ s1, Figure S1: TRPV2 expression in human EC biopsies. Figure S2: CBD treatment inhibited migration of PCEM004a cells.

Author Contributions: Conceptualization, M.N.; investigation, O.M., L.Z. and C.A. (Cristina Aguzzi); resources, F.A. and B.F.; data curation, M.B.M.; writing—original draft preparation, M.N. and O.M.; writing-review and editing, C.A. (Consuelo Amantini), D.A., S.T. and F.M.; visualization, G.S.; supervision, M.N. All authors have read and agreed to the published version of the manuscript.

Funding: This work was supported by grants from Enecta; M.B.M. was supported by Fondazione Umberto Veronesi (Post-doctoral Fellowship 2018, 2019) and O.M. from UNICAM School of Advanced Studies in Life and Health Sciences.

Acknowledgments: Thanks to Dario Conti for his support on endometrial cancer research in UNICAM. F.A. was a senior researcher for Research Foundation-Flanders (FWO). S.T. was financially supported by the Anticancer Fund (www.anticancerfund.org) and by the associated Verelst Uterine Cancer Fund, Leuven.

Conflicts of Interest: The authors declare no conflict of interest. 


\section{References}

1. Davis, M.P. Cannabinoids for Symptom Management and Cancer Therapy: The Evidence. J. Natl. Compr. Cancer Netw. 2016, 14, 915-922. [CrossRef] [PubMed]

2. Kleckner, A.S.; Kleckner, I.R.; Kamen, C.S.; Tejani, M.A.; Janelsins, M.C.; Morrow, G.R.; Peppone, L.J. Opportunities for cannabis in supportive care in cancer. Ther. Adv. Med. Oncol. 2019, 11, 1758835919866362. [CrossRef] [PubMed]

3. Hinz, B.; Ramer, R. Anti-tumour actions of cannabinoids. Br. J. Pharmacol. 2019, 176, 1384-1394. [CrossRef] [PubMed]

4. Nabissi, M.; Morelli, M.B.; Amantini, C.; Liberati, S.; Santoni, M.; Ricci-Vitiani, L.; Pallini, R.; Santoni, G. Cannabidiol stimulates Aml-1a-dependent glial differentiation and inhibits glioma stem-like cells proliferation by inducing autophagy in a TRPV2-dependent manner. Int. J. Cancer 2015, 137, 8-69. [CrossRef]

5. Ivanov, V.N.; Wu, J.; Hei, T.K. Regulation of human glioblastoma cell death by combined treatment of cannabidiol, $\gamma$-radiation and small molecule inhibitors of cell signalling pathways. Oncotarget 2017, 8 , 74068-74095. [CrossRef]

6. Vaccani, A.; Massi, P.; Colombo, A.; Rubino, T.; Parolaro, D. Cannabidiol inhibits human glioma cell migration through a cannabinoid receptor-independent mechanism. Br. J. Pharmacol. 2005, 144, 1032-1036. [CrossRef]

7. Ramer, R.; Heinemann, K.; Merkord, J.; Rohde, H.; Salamon, A.; Linnebacher, M.; Hinz, B. COX-2 and PPAR- $\gamma$ confer cannabidiol-induced apoptosis of human lung cancer cells. Mol. Cancer Ther. 2013, 12, 69-82. [CrossRef]

8. Ramer, R.; Bublitz, K.; Freimuth, N.; Merkord, J.; Rohde, H.; Haustein, M.; Borchert, P.; Schmuhl, E.; Linnebacher, M.; Hinz, B. Cannabidiol inhibits lung cancer cell invasion and metastasis via intercellular adhesion molecule-1. FASEB J. 2012, 26, 1535-1548. [CrossRef]

9. Ramer, R.; Rohde, A.; Merkord, J.; Rohde, H.; Hinz, B. Decrease of plasminogen activator inhibitor-1 may contribute to the anti-invasive action of cannabidiol on human lung cancer cells. Pharm. Res. 2010, 27, 2162-2174. [CrossRef]

10. Zhang, X.; Qin, Y.; Pan, Z.; Li, M.; Liu, X.; Chen, X.; Qu, G.; Zhou, L.; Xu, M.; Zheng, Q.; et al. Cannabidiol Induces Cell Cycle Arrest and Cell Apoptosis in Human Gastric Cancer SGC-7901 Cells. Biomolecules 2019, 9, 302. [CrossRef]

11. Sultan, A.S.; Marie, M.A.; Sheweita, S.A. Novel mechanism of cannabidiol-induced apoptosis in breast cancer cell lines. Breast 2018, 41, 34-41. [CrossRef] [PubMed]

12. Shrivastava, A.; Kuzontkoski, P.M.; Groopman, J.E.; Prasad, A. Cannabidiol induces programmed cell death in breast cancer cells by coordinating the cross-talk between apoptosis and autophagy. Mol. Cancer Ther. 2011, 10, 7-1172. [CrossRef] [PubMed]

13. Elbaz, M.; Nasser, M.W.; Ravi, J.; Wani, N.A.; Ahirwar, D.K.; Zhao, H.; Oghumu, S.; Satoskar, A.R.; Shilo, K.; Carson, W.E., 3rd; et al. Modulation of the tumor microenvironment and inhibition of EGF/EGFR pathway: Novel anti-tumor mechanisms of Cannabidiol in breast cancer. Mol. Oncol. 2015, 9, 906-919. [CrossRef]

14. Simmerman, E.; Qin, X.; Yu, J.C.; Baban, B. Cannabinoids as a Potential New and Novel Treatment for Melanoma: A Pilot Study in a Murine Model. J. Surg. Res. 2019, 235, 210-215. [CrossRef] [PubMed]

15. De Petrocellis, L.; Ligresti, A.; Schiano Moriello, A.; Iappelli, M.; Verde, R.; Stott, C.G.; Cristino, L.; Orlando, P.; Di Marzo, V. Non-THC cannabinoids inhibit prostate carcinoma growth in vitro and in vivo: Pro-apoptotic effects and underlying mechanisms. Br. J. Pharmacol. 2013, 168, 79-102. [CrossRef] [PubMed]

16. Aviello, G.; Romano, B.; Borrelli, F.; Capasso, R.; Gallo, L.; Piscitelli, F.; Di Marzo, V.; Izzo, A.A. Chemopreventive effect of the non-psychotropic phytocannabinoid cannabidiol on experimental colon cancer. J. Mol. Med. 2012, 90, 925-934. [CrossRef]

17. Sreevalsan, S.; Joseph, S.; Jutooru, I.; Chadalapaka, G.; Safe, S.H. Induction of apoptosis by cannabinoids in prostate and colon cancer cells is phosphatase dependent. Anticancer Res. 2011, 31, 3799-3807.

18. Fisher, T.; Golan, H.; Schiby, G.; PriChen, S.; Smoum, R.; Moshe, I.; Peshes-Yaloz, N.; Castiel, A.; Waldman, D.; Gallily, R.; et al. In vitro and in vivo efficacy of non-psychoactive cannabidiol in neuroblastoma. Curr. Oncol. 2016, 23, S15-S22. [CrossRef]

19. Morelli, M.B.; Offidani, M.; Alesiani, F.; Discepoli, G.; Liberati, S.; Olivieri, A.; Santoni, M.; Santoni, G.; Leoni, P.; Nabissi, M. The effects of cannabidiol and its synergism with bortezomib in multiple myeloma cell lines. A role for transient receptor potential vanilloid type-2. Int. J. Cancer 2014, 134, 2534-2546. [CrossRef] 
20. Nabissi, M.; Morelli, M.B.; Offidani, M.; Amantini, C.; Gentili, S.; Soriani, A.; Cardinali, C.; Leoni, P.; Santoni, G. Cannabinoids synergize with carfilzomib, reducing multiple myeloma cells viability and migration. Oncotarget 2016, 7, 77547-77557. [CrossRef]

21. Gallily, R.; Even-Chena, T.; Katzavian, G.; Lehmann, D.; Dagan, A.; Mechoulam, R. Gamma-irradiation enhances apoptosis induced by cannabidiol, a non-psychotropic cannabinoid, in cultured HL-60 myeloblastic leukemia cells. Leuk. Lymphoma 2003, 44, 10-1773. [CrossRef] [PubMed]

22. McKallip, R.J.; Jia, W.; Schlomer, J.; Warren, J.W.; Nagarkatti, P.S.; Nagarkatti, M. Cannabidiol-induced apoptosis in human leukemia cells: A novel role of cannabidiol in the regulation of p22phox and Nox4 expression. Mol. Pharmacol. 2006, 70, 897-908. [CrossRef] [PubMed]

23. Sharafi, G.; He, H.; Nikfarjam, M. Potential Use of Cannabinoids for the Treatment of Pancreatic Cancer. J. Pancreat. Cancer. 2019, 5, 1-7. [CrossRef] [PubMed]

24. Fonseca, B.M.; Correia-da-Silva, G.; Teixeira, N.A. Cannabinoid-induced cell death in endometrial cancer cells: Involvement of TRPV1 receptors in apoptosis. J. Physiol. Biochem. 2018, 74, 2-272. [CrossRef] [PubMed]

25. Nabissi, M.; Morelli, M.B.; Santoni, M.; Santoni, G. Triggering of the TRPV2 channel by cannabidiol sensitizes glioblastoma cells to cytotoxic chemotherapeutic agents. Carcinogenesis 2013, 34, 48-57. [CrossRef] [PubMed]

26. Morales, P.; Hurst, D.P.; Reggio, P.H. Molecular Targets of the Phytocannabinoids: A Complex Picture. Prog. Chem. Org. Nat. Prod. 2017, 103, 103-131. [CrossRef] [PubMed]

27. De Petrocellis, L.; Ligresti, A.; Moriello, A.S.; Allarà, M.; Bisogno, T.; Petrosino, S.; Stott, C.G.; Di Marzo, V. Effects of cannabinoids and cannabinoid-enriched Cannabis extracts on TRP channels and endocannabinoid metabolic enzymes. Br. J. Pharmacol. 2011, 163, 1479-1494. [CrossRef]

28. Muller, C.; Morales, P.; Reggio, P.H. Cannabinoid Ligands Targeting TRP Channels. Front. Mol. Neurosci. 2019, 11, 487. [CrossRef]

29. Pellati, F.; Borgonetti, V.; Brighenti, V.; Biagi, M.; Benvenuti, S.; Corsi, L. Cannabis sativa L. and Nonpsychoactive Cannabinoids: Their Chemistry and Role against Oxidative Stress, Inflammation, and Cancer. Biomed. Res. Int. 2018, 2018, 1691428. [CrossRef]

30. Santoni, G.; Amantini, C.; Maggi, F.; Marinelli, O.; Santoni, M.; Nabissi, M.; Morelli, M.B. The TRPV2 cation channels: From urothelial cancer invasiveness to glioblastoma multiforme interactome signature. Lab. Investig. 2020, 100, 186-198. [CrossRef]

31. Caprodossi, S.; Lucciarini, R.; Amantini, C.; Nabissi, M.; Canesin, G.; Ballarini, P.; Di Spilimbergo, A.; Cardarelli, M.A.; Servi, L.; Mammana, G.; et al. Transient Receptor Potential Vanilloid Type 2 (TRPV2) Expression in Normal Urothelium and in Urothelial Carcinoma of Human Bladder: Correlation with the Pathologic Stage. Eur. Urol. 2008, 54, 612-620. [CrossRef] [PubMed]

32. Yamada, T.; Ueda, T.; Shibata, Y.; Ikegami, Y.; Saito, M.; Ishida, Y.; Ugawa, S.; Kohri, K.; Shimada, S. TRPV2 activation induces apoptotic cell death in human T24 bladder cancer cells: A potential therapeutic target for bladder cancer. Urology 2010, 76, 509.e1-509.e7. [CrossRef] [PubMed]

33. Oulidi, A.; Bokhobza, A.; Gkika, D.; Vanden Abeele, F.; Lehen'kyi, V.; Ouafik, L.; Mauroy, B.; Prevarskaya, N. TRPV2 mediates adrenomedullin stimulation of prostate and urothelial cancer cell adhesion, migration and invasion. PLoS ONE 2013, 8, e64885. [CrossRef] [PubMed]

34. Monet, M.; Gkika, D.; Lehen'kyi, V.; Pourtier, A.; Vanden Abeele, F.; Bidaux, G.; Juvin, V.; Rassendren, F.; Humez, S.; Prevarsakaya, N. Lysophospholipids stimulate prostate cancer cell migration via TRPV2 channel activation. Biochim. Biophys. Acta 2009, 1793, 3-539. [CrossRef] [PubMed]

35. Monet, M.; Lehen'kyi, V.; Gackiere, F.; Firlej, V.; Vandenberghe, M.; Roudbaraki, M.; Gkika, D.; Pourtier, A.; Bidaux, G.; Slomianny, C.; et al. Role of cationic channel TRPV2 in promoting prostate cancer migration and progression to androgen resistance. Cancer Res. 2010, 70, 3-1235. [CrossRef] [PubMed]

36. Makker, A.; Goel, M.M. Tumor progression, metastasis, and modulators of epithelial-mesenchymal transition in endometrioid endometrial carcinoma: An update. Endocr. Relat. Cancer 2016, 23, R85-R111. [CrossRef] [PubMed]

37. Sonoda, K. Molecular biology of gynecological cancer. Oncol. Lett. 2016, 1, 16-22. [CrossRef]

38. Arora, E.; Masab, M.; Mittar, P.; Jindal, V.; Gupta, S.; Dourado, C. Role of immune checkpoint inhibitors in advanced or recurrent endometrial cancer. Cureus 2018, 10, e2521. [CrossRef]

39. Ayakannu, T.; Taylor, A.H.; Konje, J.C. Cannabinoid receptor expression in estrogen-dependent and estrogen-independent endometrial cancer. J. Recept. Signal Transduct. Res. 2018, 38, 385-392. [CrossRef] 
40. De Clercq, K.; Held, K.; Van Bree, R.; Meuleman, C.; Peeraer, K.; Tomassetti, C.; Voets, T.; D’Hooghe, T.; Vriens, J. Functional expression of transient receptor potential channels in human endometrial stromal cells during the luteal phase of the menstrual cycle. Hum. Reprod. 2015, 30, 1421-1436. [CrossRef]

41. Persoons, E.; Hennes, A.; De Clercq, K.; Van Bree, R.; Vriens, G.; O, D.F.; Peterse, D.; Vanhie, A.; Meuleman, C.; Voets, T; et al. Functional Expression of TRP Ion Channels in Endometrial Stromal Cells of Endometriosis Patients. Int. J. Mol. Sci. 2018, 19, 2467. [CrossRef]

42. Nabissi, M.; Amant, F.; Gehrig, P. Endometrial Cancer: From Biological to Clinical Approaches; Frontiers Media: Lausanne, Switzerland, 2019. [CrossRef]

43. Remmerie, M.; Janssens, V. Targeted Therapies in Type II Endometrial Cancers: Too Little, but Not Too Late. Int. J. Mol. Sci. 2018, 19, 2380. [CrossRef] [PubMed]

44. Taylor, C.R.; Cooper, C.L.; Kurman, R.J.; Goebelsmann, U.; Markland, F.S., Jr. Detection of estrogen receptor in breast and endometrial carcinoma by the immunoperoxidase technique. Cancer 1981, 47, 2634-2640. [CrossRef]

45. Guida, M.; Ligresti, A.; De Filippis, D.; D'Amico, A.; Petrosino, S.; Cipriano, M.; Bifulco, G.; Simonetti, S.; Orlando, P.; Insabato, L.; et al. The levels of the endocannabinoid receptor CB2 and its ligand 2-arachidonoylglycerol are elevated in endometrial carcinoma. Endocrinology 2010, 151, 921-928. [CrossRef]

46. Zhou, K.; Zhang, S.S.; Yan, Y.; Zhao, S. Overexpression of transient receptor potential vanilloid 2 is associated with poor prognosis in patients with esophageal squamous cell carcinoma. Med. Oncol. 2014, 31, 7. [CrossRef] [PubMed]

47. Bai, H.; Zhu, H.; Yan, Q.; Shen, X.; Lu, X.; Wang, J.; Li, J.; Chen, L. TRPV2-induced Ca(2+)-calcineurin NFAT signaling regulates differentiation of osteoclast in multiple myeloma. Cell Commun. Signal 2018, 16, 1. [CrossRef]

48. Zoppoli, P.; Calice, G.; Laurino, S.; Ruggieri, V.; La Rocca, F.; La Torre, G.; Ciuffi, M.; Amendola, E.; De Vita, F.; Petrillo, A.; et al. TRPV2 Calcium Channel Gene Expression and Outcomes in Gastric Cancer Patients: A Clinically Relevant Association. J. Clin. Med. 2019, 8, 662. [CrossRef]

49. Liberati, S.; Morelli, M.B.; Amantini, C.; Farfariello, V.; Santoni, M.; Conti, A.; Nabissi, M.; Cascinu, S.; Santoni, G. Loss of TRPV2 Homeostatic Control of Cell Proliferation Drives Tumor Progression. Cells 2014, 3 , 112-128. [CrossRef]

50. Neumann-Raizel, H.; Shilo, A.; Lev, S.; Mogilevsky, M.; Katz, B.; Shneor, D.; Shaul, Y.D.; Leffler, A.; Gabizon, A.; Karni, R.; et al. 2-APB and CBD-Mediated Targeting of Charged Cytotoxic Compounds Into Tumor Cells Suggests the Involvement of TRPV2 Channels. Front. Pharmacol. 2019, 10, 1198. [CrossRef]

51. Fraguas-Sánchez, A.I.; Fernández-Carballido, A.; Simancas-Herbada, R.; Martin-Sabroso, C.; Torres-Suárez, A.I. CBD loaded microparticles as a potential formulation to improve paclitaxel and doxorubicin-based chemotherapy in breast cancer. Int. J. Pharm. 2020, 574, 118916. [CrossRef]

52. López-Valero, I.; Saiz-Ladera, C.; Torres, S.; Hernández-Tiedra, S.; García-Taboada, E.; Rodríguez-Fornés, F.; Barba, M.; Dávila, D.; Salvador-Tormo, N.; Guzmán, M.; et al. Targeting Glioma Initiating Cells with A combined therapy of cannabinoids and temozolomide. Biochem. Pharmacol. 2018, 157, 266-274. [CrossRef] [PubMed]

53. Torres, S.; Lorente, M.; Rodríguez-Fornés, F.; Hernández-Tiedra, S.; Salazar, M.; García-Taboada, E.; Barcia, J.; Guzmán, M.; Velasco, G. A combined preclinical therapy of cannabinoids and temozolomide against glioma. Mol. Cancer Ther. 2011, 10, 1-103. [CrossRef]

54. Levy, J.M.M.; Towers, C.G.; Thorburn, A. Targeting autophagy in cancer. Nat. Rev. Cancer. 2017, 17, 528-542. [CrossRef] [PubMed]

55. Jeong, S.; Kim, B.G.; Kim, D.Y.; Kim, B.R.; Kim, J.L.; Park, S.H.; Na, Y.J.; Jo, M.J.; Yun, H.K.; Jeong, Y.A.; et al. Cannabidiol Overcomes Oxaliplatin Resistance by Enhancing NOS3- and SOD2-Induced Autophagy in Human Colorectal Cancer Cells. Cancers 2019, 11, 781. [CrossRef] [PubMed]

56. Fitzgibbons, P.L.; Dillon, D.A.; Alsabeh, R.; Berman, M.A.; Hayes, D.F.; Hicks, D.G.; Hughes, K.S.; Nofech-Mozes, S. Template for reporting results of biomarker testing of specimens from patients with carcinoma of the breast. Arch. Pathol. Lab. Med. 2014, 138, 595-601. [CrossRef] 